\title{
Surface Morphologies in a Mars-Analog Ca-Sulfate Salar, High Andes, Northern Chile
}

\begin{abstract}
Nancy W. Hinman ${ }^{1 *}$, Michael H. Hofmann ${ }^{1}$, Kimberly Warren-Rhodes ${ }^{2}$, Michael S. Phillips ${ }^{3}$, Nora Noffke ${ }^{4}$, Nathalie A. Cabrol ${ }^{5}$, Guillermo Chong Diaz ${ }^{6}$, Cecilia Demergasso ${ }^{7}$, Cinthya Tebes-Cayo ${ }^{7}$, Oscar Cabestrero ${ }^{6}$, Janice L. Bishop ${ }^{2}$, Virginia C. Gulick ${ }^{2,8}$, David Summers ${ }^{2}$, Pablo Sobron ${ }^{2}$, Michael Mclnenly ${ }^{1}$, Jeffrey Moersch ${ }^{3}$, Constanza Rodriguez ${ }^{6}$, Philippe Sarazzin ${ }^{2}$, Kevin L. Rhodes ${ }^{9}$, Camila Javiera Riffo Contreras ${ }^{6}$, David Wettergreen ${ }^{10}$ and Victor Parro ${ }^{11}$ on behalf of the SETI NAI team

${ }^{1}$ Department of Geosciences, University of Montana, Missoula, MT, United States, ${ }^{2}$ SETI Institute, Mountain View, CA, United States, ${ }^{3}$ Department of Earth and Planetary Science, The University of Tennessee, Knoxville, TN, United States, ${ }^{4}$ Ocean, Earth, and Atmospheric Sciences, Old Dominion University, Norfolk, VA, United States, ${ }^{5}$ Carl Sagan Center, SETI Institute, Mountainview, CA, United States, ${ }^{6}$ Departmento de Ciencias Geológicas, Catholic University of the North, Antofagasta, Chile, ${ }^{7}$ Center for Biotechnology, Catholic University of the North, Antofagasta, Chile, ${ }^{8}$ Ames Research Center, National Aeronautics and Space Administration (NASA), Moffet Field, CA, United States, ${ }^{9}$ MAR Alliance, San Francisco, CA, United States, ${ }^{10}$ Robotics Institute, Carnegie Mellon University, Pittsburgh, PA, United States, ${ }^{11}$ Center for Astrobiology, Spanish National Research Council (CSIC), Madrid, Spain
\end{abstract}

Queensland University of Technology,

Brisbane, Australia

Reviewed by:

Akos Kereszturi,

Hungarian Academy of Sciences

(MTA), Hungary

Monica Pondrelli,

Università d'Annunzio, Pescara, Italy

*Correspondence:

Nancy W. Hinman

nancy.hinman@umontana.edu

Specialty section:

This article was submitted to

Astrobiology,

a section of the journal

Frontiers in Astronomy and Space

Sciences

Received: 18 October 2021 Accepted: 01 December 2021

Published: 07 February 2022

Citation:

Hinman NW, Hofmann MH, Warren-Rhodes K, Phillips MS, Noffke N, Cabrol NA, Chong Diaz G,

Demergasso C, Tebes-Cayo C, Cabestrero O, Bishop JL, Gulick VC, Summers $D$, Sobron $P$, Mclnenly $M$, Moersch J, Rodriguez C, Sarazzin $P$,

Rhodes KL, Riffo Contreras CJ,

Wettergreen D and Parro V (2022)

Surface Morphologies in a MarsAnalog Ca-Sulfate Salar, High Andes, Northern Chile.

Front. Astron. Space Sci. 8:797591. doi: 10.3389/fspas.2021.797591
Salar de Pajonales, a Ca-sulfate salt flat in the Chilean High Andes, showcases the type of polyextreme environment recognized as one of the best terrestrial analogs for early Mars because of its aridity, high solar irradiance, salinity, and oxidation. The surface of the salar represents a natural climate-transition experiment where contemporary lagoons transition into infrequently inundated areas, salt crusts, and lastly dry exposed paleoterraces. These surface features represent different evolutionary stages in the transition from previously wetter climatic conditions to much drier conditions today. These same stages closely mirror the climate transition on Mars from a wetter early Noachian to the Noachian/Hesperian. Salar de Pajonales thus provides a unique window into what the last near-surface oases for microbial life on Mars could have been like in hypersaline environments as the climate changed and water disappeared from the surface. Here we open that climatological window by evaluating the narrative recorded in the salar surface morphology and microenvironments and extrapolating to similar paleosettings on Mars. Our observations suggest a strong inter-dependence between small and large scale features that we interpret to be controlled by extrabasinal changes in environmental conditions, such as precipitation-evaporation-balance changes and thermal cycles, and most importantly, by internal processes, such as hydration/dehydration, efflorescence/deliquescence, and recrystallization brought about by physical and chemical processes related to changes in groundwater recharge and volcanic processes. Surface structures and textures record a history of hydrological changes that impact the mineralogy and volume of Ca-sulfate layers comprising most of the salar surface. Similar surface features on Mars, interpreted as products of freeze-thaw cycles, could, instead, be products of waterdriven, volume changes in salt deposits. On Mars, surface manifestations of such salt-related processes would point to potential water sources. Because hygroscopic salts have been invoked as sources of localized, transient water sufficient to support terrestrial life, such structures might be good targets for biosignature exploration on Mars.

Keywords: mars, evaporite, salt pan, gypsum (CaSO 2H O) 4 2, Chile, Andes, Salar 


\section{INTRODUCTION}

The Andean Salar de Pajonales (3,537 $\mathrm{m}$ asl, $25^{\circ} 08^{\prime} 40^{\prime \prime} \mathrm{S}$, $68^{\circ} 49^{\prime} 12^{\prime \prime} \mathrm{W}$; Figure 1) is an evaporitic basin located on the western margin of the High Andes in the Altiplano ${ }^{1}$. At present, it is in the desiccation period of wetting and drying cycles, comprising lagoons/salt ponds, salt crusts, infrequently inundated areas, and dry exposed paleoterraces (Chong Diaz et al., 2020).

The hydrological progression from active lagoons to exposed salt paleoterraces forms a natural climate-transition experiment, where each salar surface represents a different stage of evolution in the wet-to-dry transitions during (micro-)cycles of climate change over geological time scales. The climate transition exemplified at Salar de Pajonales partly mirrors that postulated for early Mars (Kite, 2019; Wordsworth et al., 2021), thus making it a unique terrestrial analog for early climate change on that planet (Cabrol et al., 2009; Cabrol et al., 2010; Cabrol, 2018; Farías and Acuña, 2020; Pueyo et al., 2021).

At present, the High Andes are characterized by daily occurrences of dust devils and enhanced evaporation (-1,500 mm/yr) (Cabrol and Grin, 2010; Benison, 2017). Indeed, surface measurements in the High Andes recorded the highest solar radiation levels on Earth, including UVB (Cabrol et al., 2014; Albarracin et al., 2015; Häder and Cabrol, 2018; Häder and Cabrol, 2020). The thin atmosphere produces sudden and sharp daily temperature $(\mathrm{T})$ and relative humidity (Warren-Rhodes et al., in review; Kereszturi et al., 2020) fluctuations that generate high UV/ $\mathrm{T}$ ratios further extending the Salar de Pajonales region's environmental analogies to Martian conditions.

Salar de Pajonales furnishes a window into the possible last microbial refugia on Mars as the climate shifted and water disappeared from the surface (Davila and Schulze-Makuch, 2016) Here we open that climatological window by evaluating the morphological and mineralogical properties of the salar and its implications for evaporitic basins on Mars during the Noachian through early Hesperian (Cabrol et al., 2018; Kite, 2019; Wordsworth et al., 2021). We test the hypothesis that hydrological processes on a time scale relevant to recent climate changes, coupled with volcanic processes, are the major control on surface morphology in this Martian analog. If true, then these morphologies could reflect similar hydrological conditions during the wetter climate of early Mars and could guide site and sample selection-going beyond the "follow the water" model for on-going and upcoming Mars missions.

\subsection{Site Overview}

Salar de Pajonales (Figure 1) is a large $\left(104 \mathrm{~km}^{2}\right)$ salt flat that lies in a high elevation basin on the western margin of the High Andes in northern Chile to the east of the Atacama Desert-a well-

\footnotetext{
${ }^{1}$ It should be noted that this high elevation desert is known as the Puna in Argentina and the (Chilean) Altiplano in Chile and Bolivia, and is sometimes referred to as the Atacama Altiplano or as an extension of the Atacama Desert in Chile (e.g., Farias and Acuña, 2020; Wierzchos et al., 2020). This observation is provided to clarify the physiographic location of Salar de Pajonales relative to other high-elevation study sites.
}

described Martian analog (Cabrol et al., 2001; Cabrol et al., 2007; Gómez-Silva et al., 2008; Gómez-Silva, 2010; Artieda et al., 2015; Wilhelm et al., 2018; Kereszturi et al., 2020).

The Andes Mountain arise from the subduction of the Nazca plate beneath the South American Plate since the Upper Triassic-Early Jurassic (Haschke et al., 2002; Haschke et al., 2006). The subduction activity created the Andean arc magmatism, which has been practically continuous to the present (Charrier et al., 2007). Along this geological time span different paleogeographic changes took place. The physiographic provinces change with latitude but follow a general discontinuous pattern of N-S trending orogens separated by intermontane valleys. In Northern Chile $\left(\sim 18^{\circ} \mathrm{S}\right.$ to $\left.27^{\circ} \mathrm{S}\right)$, the order from west-to-east is the Coastal Cordillera, the Central Depression (Longitudinal Valley), the PreCordillera, and the Preandean Depression (Salar de Atacama/Salar de Punta Negra Depression), the Western or Volcanic Cordillera, which overlies the Altiplano-Puno of Northern Chile and, in Argentina, the Eastern Cordillera or Cordillera Oriental (Eocene to Pliocene), and the Subandean

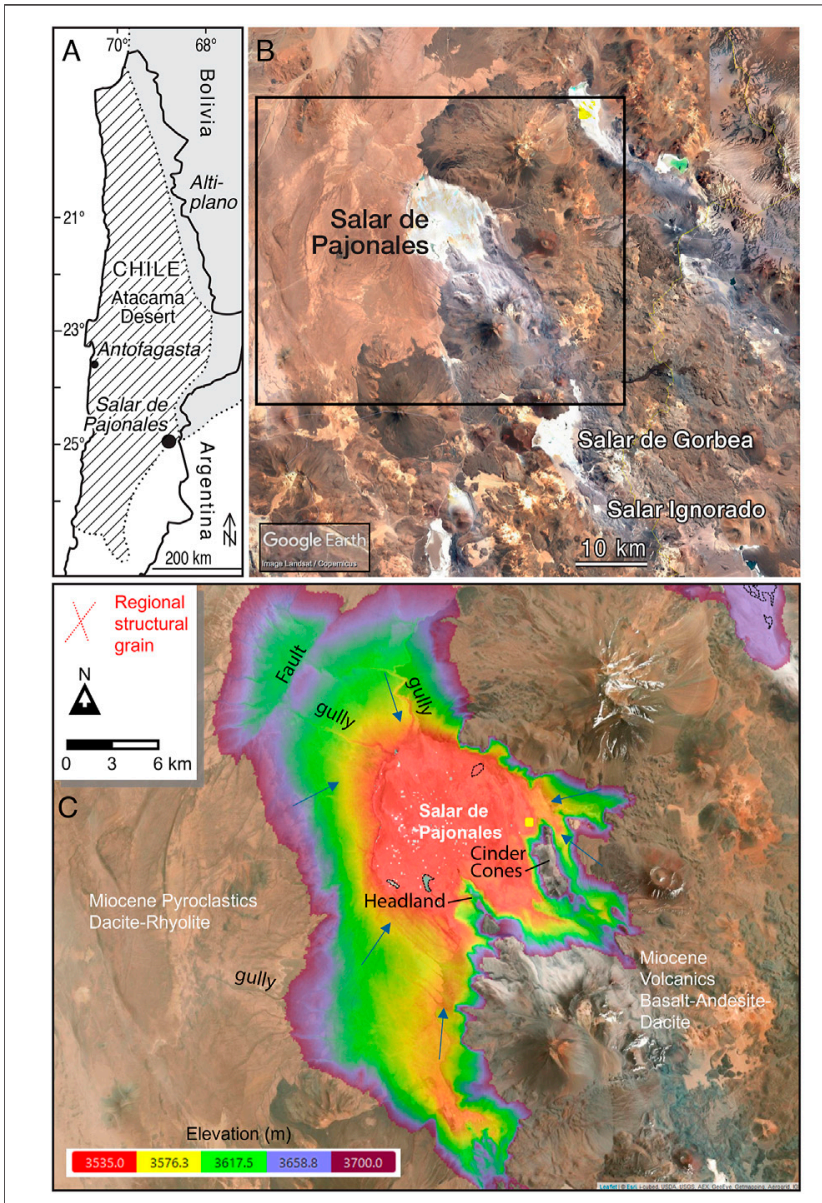

FIGURE 1 | Location of study area. (A) Map of Chile. (B) Overview of Salar de Pajonales. (C) Truncated digital elevation model (DEM) of the study site composed in the Cartalytics (www.cltix.com) spatial data software; aerial imagery is downloaded from the Leaflet open-source library (https:// leafletjs.com/) 
and Santa Bárbara Ranges (Jordan et al., 1983; Rehak et al., 2010; DeCelles et al., 2015; Quade et al., 2015; Reiners et al., 2015; Chong Diaz et al., 2020; Wierzchos et al., 2020).

The physiographic regions of Northern Chile $\left(18^{\circ}-27^{\circ} \mathrm{S}\right)$ are characterized by a temporal and compositional progression of Cenozoic salt deposits at the surface most often expressed as salt flats (e.g., Artieda et al., 2015; Finstad et al., 2016; Alonso and Rojas, 2020; Chong Diaz et al., 2020). In west-to-east order, the Coastal Range hosts the oldest salt flats; these are inactive and fossilized. Inland to the east are the salt flats of the Central Depression and the Preandean salt flats located at the western border of the Precordillera (i.e., Salar de Atacama). The youngest are the Andean salt flats and saline lakes emplaced in basins of the Altiplano.

Salar de Pajonales is located in the Altiplano at the foothills of the Sierra de Varas, which form the western side of the endorheic depression (Riquelme et al., 2007; Pfeiffer et al., 2018). Miocene to Recent volcanoes of the Western Cordillera form the salar's eastern border (Figure 1).

Oligocene to Holocene volcanic rocks of the Altiplano comprise basaltic to dacitic and rhyolitic extrusives that erupted from 10-11 Ma to <1 Ma (DeCelles et al., 2015), and volcanic activity continues today (Quade et al., 2015). The main eruptive centers near the salar are Lastarria to the east and Llullaillaco to the north in the Western Cordillera (Risacher and Alonso, 2001; Robidoux et al., 2020) (Supplementary Figure S1). Lastarria has not erupted in recorded history but continues intense fumarolic activity (Global Volcanism Program, 2013). Llullaillaco erupted most recently in the 19th Century (Casertano, 1963). This volcanic activity influences the chemistry of the adjacent salars (Risacher et al., 2003; Chong Diaz et al., 2020). Salar de Pajonales is thus set within the wider Andean landscape (Artieda et al., 2015) of sulfur-rich volcanic, hydrothermal, lacustrine, and aeolian deposits (Chong Diaz et al., 2020).

Salar de Pajonales is a hydrologically active evaporitic system. Brines that fill the remaining active lagoons in the lower elevation portions of Salar de Pajonales are formed by a combination of atmospheric aerosol input, volcanic emissions, chemical weathering of country rock, and high rates of evaporation relative to precipitation (Risacher et al., 2003; Chong Diaz et al., 2020; Otalora et al., 2020; Pueyo et al., 2021). During the transition to the more arid climate of today, episodic evaporation of the brines and inundation of the basin left an evaporite package several meters thick (Figure 2; see below). At present, the basin receives recharge from both surface water (Risacher et al., 2003) and, by inference from other endorheic basins, groundwater, which originates from the volcanic arc of the Andes to the east (Urrutia et al., 2018; Chong Diaz et al., 2020; Pueyo et al., 2021).

\subsection{Climate}

Climate records, extensively reviewed by Pfeiffer et al. (2018) from the Atacama Desert, Altiplano, and Puna indicate wet periods since the Pleistocene, most notably during the Minchin phase (35-23 ka), the MIS $2(\sim 26.5-22 \mathrm{ka})$, the Tauca highstand $(\sim 17.5-15 \mathrm{ka})$, and in late glacial times (i.e., Younger

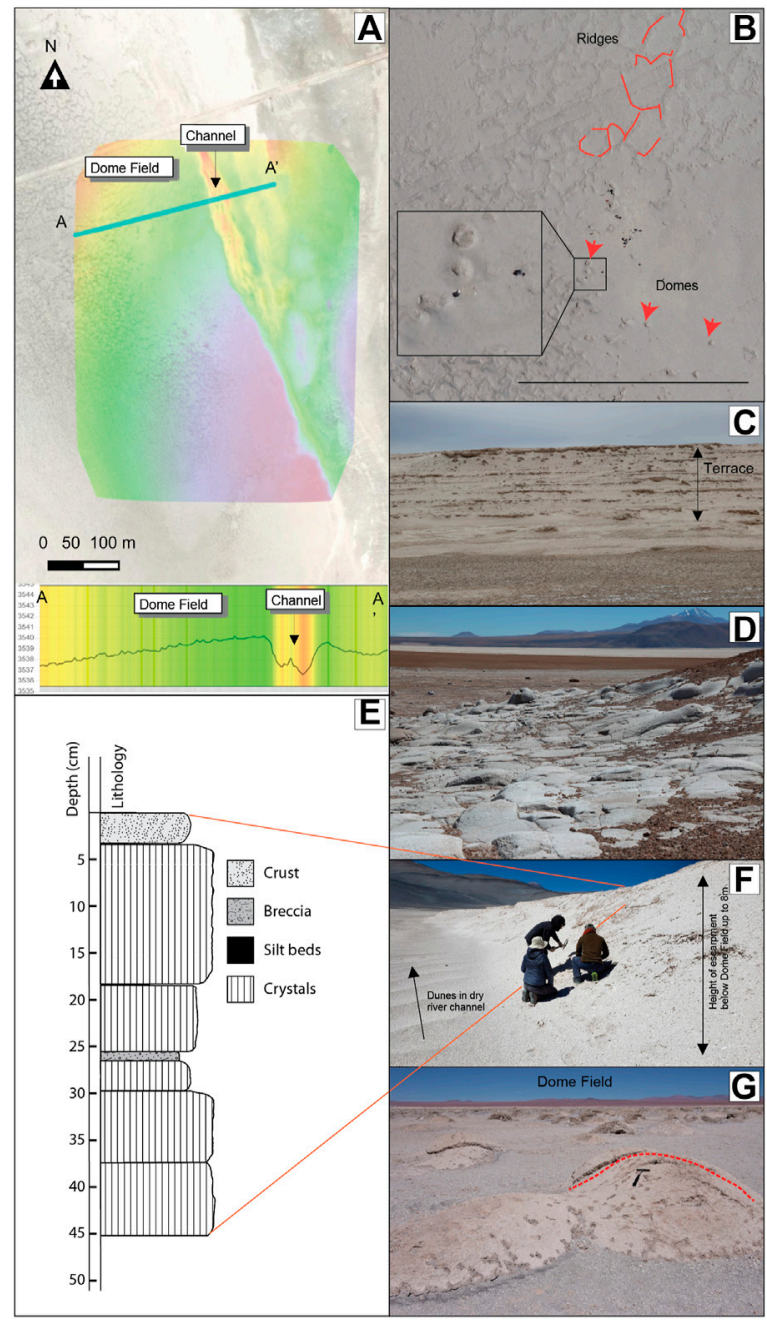

FIGURE 2 | (A) Shaded DEM of study area with A-A' elevation transect. Maps and cross section were created in Cartalytics (www.cltix.com); aerial imagery is downloaded from the Leaflet open-source library (https://leafletjs. com/). (B) Air photo of study site with Domes (red arrows) and randomly oriented ridge segments that connect to form irregular Megapolygons (outlined in dashed red lines). (C) Paleoterraces of exposed gypsum beds. (D) Rhyolite surface eroded by abrasive flooding. Field of vew ca $25 \mathrm{~m}$. (E) Drainage cut through gypsum bed looking south. The Dome Field is to the right on the top of the gypsum terrace. (F) Stratigraphy column illustrating cyclic deposition in the upper $0.5 \mathrm{~m}$ of salar surface at the Dome Field. The surface layer is a coherent but breakable crust of cemented grains extending downward between crystals from the underlying layer. Crystal beds are vertically oriented selenite. Silt beds are thin, recessive laminar beds comprising detrital crystals and grains. Breccia layers comprise flat lying selenite that is very friable. (G) Dome field looking west. A dashed red line highlights the dome in the center right.

Dryas, 13-10 ka; Coipasa, 13-11 ka) (e.g., for Chile: Geyh et al., 1999; Ward et al., 2015; Ward et al., 2017; Pfeiffer et al., 2018; Palacios et al., 2020) ${ }^{2}$. At present, there are no confirmed glacial

${ }^{2}$ The dates are somewhat different to the east in the Bolivian Altiplano, but the sequence remains the same (Chepstow-Lusty et al., 2005). 
landforms recorded in the Salar de Pajonales area (Palacios et al., 2020), suggesting that glacial processes did not directly influence the basin during the last glacial period. Gypsum beds exposed in paleoterraces testify to higher lake stands and thicker lake fill, much of which has been removed by surface runoff (Figures 2C,E).

During the late glacial wet periods, precipitation is inferred to have been $2-5$ times higher than present day $(\sim 200 \mathrm{~mm} / \mathrm{yr}$; (Grosjean et al., 2001; Latorre et al., 2006; Ward et al., 2015). Lake levels in the Altiplano reached their maximum between 10.8 and $9.2 \mathrm{ka}$ and disappeared sometime between 8.4 and $8.0 \mathrm{ka}$ (Geyh et al., 1999). Since then, the climate has been extremely arid except for brief wetter periods, the most recent being probably from the same time $(1.39+/-0.10 \mathrm{ka})$ as that of the Gorbea and Ignorado salt flats located $\sim 40 \mathrm{~km}$ south of Salar de Pajonales and at higher elevation (Figure 1; 4000 $\mathrm{m}$ asl (Pueyo et al., 2021). Other climate records, found in fossilized rodent middens, wetland deposits, and archeological sites also reflect wetter time periods within the last $90 \mathrm{ka}$ (Chepstow-Lusty et al., 2005; Maldonado et al., 2005; Díaz et al., 2012; Pfeiffer et al., 2021).

Historic, significant rainfall events, which occur episodically, flood salar surfaces and lead to increased biodiversity (SchulzeMakuch et al., 2018; Ortega et al., 2019; Pfeiffer et al., 2021). The frequency and intensity of these freshening events have changed over the last $106 \mathrm{ka}$ based on a $100 \mathrm{~m}$ core from Salar de Atacama (Bobst et al., 2001). Such events are controlled by the complex hydrometeorological patterns of the southern Pacific Ocean. The more usual configuration of SE Trade Winds bringing moisturedepleted air over the Andes is disrupted episodically (Garreaud et al., 2009; Diederich et al., 2020). These interruptions are known as El Niño events, which are linked to high sea-surface temperatures in the eastern Pacific Ocean (Garreaud et al., 2009; Bozkurt et al., 2016; Urrutia et al., 2019). This relatively common weather pattern, which is part of the El Niño Southern Oscillation (ENSO), disrupts the southeasterly trade winds and allows moist air to flow inland from the warm Pacific Ocean leading to austral winter precipitation events in parts of the Atacama desert (Houston and Hartley, 2003; Houston, 2006; Diederich et al., 2020; Meseguer-Ruiz et al., 2020). However, El Niño events have a different effect on the Altiplano. There they lead to negative precipitation while La Niña years yield wetter seasons (Garreaud et al., 2003; Urrutia et al., 2019). These extreme events are associated with the Madden-Julian Oscillation during which sea surface temperatures increase in the southeastern Pacific Ocean, effectively blocking the normal westerly Ferrellcell flow and diverting moisture toward north-central Chile (Ortega et al., 2019). Monsoonal summer rain events are tied to normal northeasterly airflow from the Atlantic Ocean, over the Amazon basin, and to the Andean mountain range (Garreaud, 2000; Garreaud et al., 2003; Diederich et al., 2020).

Salar de Pajonales lies in the Arid Diagonal on the divide between regions of dominantly winter rain (generally to the west and south) and dominantly summer (monsoonal) rain (generally to the east and north) (Betancourt et al., 2000; Diederich et al., 2020; Hooper et al., 2020; Palacios et al., 2020, see their Figure 1) and is subject to infrequent freshening events (Bozkurt et al., 2016). Recent rainfall events caused significant flooding and destruction along rivers in the southern reaches of the Atacama Desert (Barrett et al., 2016; Bozkurt et al., 2016; Wilcox et al., 2016; Valdés-Pineda et al., 2017; Cabre et al., 2020) but were insufficient, in large part, to mobilize hillslopes. Most fluvial features suggest that much larger rain events occurred in the Pleistocene (Pfeiffer et al., 2021). At that time, large river systems drained westward into the Central Depression (Garcia et al., 2011). Unlike the Calama Basin where the Rio Loa cuts through the Domeyko Cordillera (De Wet et al., 2020), there is no geomorphic evidence of large rivers that drained to the Pacific Ocean from the Salar de Pajonales area. However, post-glacial flooding events are inferred along the eastern and much of the southern margin of the salar where large portions of volcanic rhyolitic basement are eroded flat by abrasive flooding (Figure 2D, Chong Diaz, unpubl.).

\section{METHODS}

Here, we used field observations to spatially resolve surface features that can be explored for different textural surfaces as defined by distinct physical, chemical, and hydrological conditions. Detailed descriptions are provided in the figure caption illustrating each characteristic (see below). Additional laboratory analyses confirmed and augmented field observations. This paper relates and refers to two other works that present results about the surface features, the threshold for detection from drone and satellite imagery, and on the distribution of microbial colonies within habitats (Phillips et al., 2021 in prep.; WarrenRhodes et al., in review).

\subsection{Site Selection}

The Dome Field study site is in the eastern area of Salar de Pajonales. It stands about $8 \mathrm{~m}$ above a dry river channel that bounds the study area on the eastern and southern sides (Figure 2). From the study site, the salar surface slopes irregularly toward the west eventually giving way to watersaturated salt flats and ponds. Within the larger Martian analog site, this Dome Field was selected because of the presence of endolithic photosynthetic microbial communities (Warren-Rhodes et al., in review). The features described herein provided visual access to the subsurface allowing us to probe the processes leading to the development of the surface morphology.

\subsection{Field observations}

Visual observations of the shape, size, and distribution of surface features were made during three field campaigns (Oct. 2016-Oct. 2019).

\subsection{Aerial imagery}

Aerial images were collected with a Phantom 4 Professional drone at an elevation of $120 \mathrm{~m}$ above the salar surface, which corresponds to a ground sampling distance of $\sim 2.5-3.0 \mathrm{~cm}$. An orthophotomosaic (OPM) and digital elevation model (DEM) 
were generated from the images using Pix $4 \mathrm{D}$, a structure from motion software package, to enable measurements and analyses of landforms and textures. See Phillips et al. (2021) (in prep.) for additional information.

\subsection{Sample Collection}

Fist-sized samples were collected from the surface down to a maximum depth of $12 \mathrm{~cm}$ with a rock hammer and placed in plastic bags. The samples were selected to represent the range of surface types and textures.

\subsection{Photomosaic}

Samples were photographed with a hand-held camera (Sony alpha 6,000) and/or a Insight Spot 4 camera (Diagnostic Instruments, Sterling Heights, MI) mounted on a Leica MZ95 stereoscope (Wetzlar, Germany). Photomosaics were prepared using the Adobe Photoshop automated merge function.

\subsection{X-ray diffractometry}

Field samples were analyzed at two laboratories and the results were compared. One set was powdered $(<63 \mu \mathrm{m})$ and analyzed from 2 to $70^{\circ} 2 \Theta$ at a step size of $0.017^{\circ} 2 \Theta$ with a PANalytical $\mathrm{X}$-Pert Pro MPD X-ray diffractometer with a $\mathrm{Cu}$ X-ray tube (Ka1 $1.54060 \AA, 45 \mathrm{~mA}, 40 \mathrm{kV})$. The data were pattern-matched and Reitveld-refined with High Score Plus (Malvern PANalytical, Inc., Netherlands) using the ICDD PDF-4 Minerals database (ICDD, Newtown Square, PA). The other set was powdered $(<20 \mu \mathrm{m})$ and analyzed from 2 to $65^{\circ} 2 \Theta$ at a step size of $0.02^{\circ} 2 \Theta$ on a Bruker D8 Advance diffractometer with Cu X-ray tube (Ka1 1.54051 $30 \mathrm{~mA}, 40 \mathrm{kV})$. The data were pattern-matched with Sieve (ICDD, Newtown Square, PA, United States) and quantified with the software, DIFFRAC. EVA (Bruker, Billerica, MA, United States) using the ICDD PDF-2 and PDF-4/Minerals database. Major minerals were detected (signal/noise 3) by both systems.

\subsection{Optical microscopy}

Twenty three field samples were selected for thin section preparation to represent different textures and provide spatial distribution. Samples were stabilized with blue-dyed resin and vertically oriented prior to cutting. Single-side polished, $30 \mu \mathrm{m}$, thin sections were prepared by Spectrum Petrographics, Inc. (Vancouver, WA, United States). Samples were imaged in transmitted and reflected light modes with a Leica DMLP petrographic microscope equipped with a Leica MC170HD camera.

\subsection{Spectroscopy}

Raman spectroscopy measurements were performed on a custom Raman spectrometer with a Raman probe (Impossible Sensing, St. Louis, MO, United States). We performed our Raman analyses in the field using optical fibers housed in a single cable to transmit the laser $(532 \mathrm{~nm})$ to the sample and to transfer the Raman signal from the sample to a TE-cooled CCD spectrometer and detection system. The recorded spectra were compared to existing spectral databases of minerals (Lafuente et al., 2015). Infrared (IR) spectra were taken with using Thermo Scientific Nicolet iN10 MX FTIR Microscope. Spectra were taken in "reflectance mode." In that mode, the beam passes through the sample, is reflected off the gold surface, and passes through the sample again. The spectrum are absorption spectra, not reflectance spectra, the light passes through the sample. The spectra were taken at $4 \mathrm{~cm}^{-1}$ resolution with liquid nitrogen cooling of the detector. Spectra were taken from $7,000 \mathrm{~cm}^{-1}$ to $700 \mathrm{~cm}^{-1}$. We used a square IR beam with a width of $75 \mu \mathrm{m}$. Powder samples were placed on top of a gold-coated glass slide. The particles were smaller than the beam, so aggregates of particles were observed to maximize signal.

\section{RESULTS}

Diffraction data from powdered samples showed that the study site comprised almost entirely gypsum (Supplementary Figure S2). XRD or Raman and VNIR spectra show additional Ca-sulfate phases, along with small quantities of calcite, halite, magnetite, and plagioclase (Table 1, Supplementary Figure S2).

These gypsum deposits are bedded on a decimeter scale, and a cyclic deposition can be inferred from the stacking of thin beds comprising well-developed gypsum crystals inter-layered with thinner beds of gypsum breccia (Figure 2). The lateral continuity of individual gypsum layers is unknown, but a largely layer-cake stratigraphy within the study area can be inferred.

In this gypsum-dominated environment, surface structures can be distinguished into two groups based on spatial scale (Table 2). Macroscale structures have dimensions centered on the meter scale and above. They affect multiple gypsum layers, however, the maximum depth to which these feature extend into the subsurface cannot be determined by our available dataset. These macroscale structures are distinct from centimeter to millimeter scale structures, herein called microscale structures. The latter only affect the surfaces of individual, thin beds. Further, the microscale structures are often superimposed on the macroscale structures. Surfaces of microscale structures have one or more textures at the centimeter to millimeter scale.

All of our interpretations on these geomorphic structures, independent of scale, are based on observations of the surface layer; our data do not allow interpretation of facies stacking and associated morphologic structures with depth.

\subsection{Macroscale Structures}

Macroscale structures are summarized in Table $\mathbf{2}$ and include PolygonRidges, Megapolygons, Domes, and Quasi-Flat areas. We describe these endmembers below but recognize that there is overlap among the structures. For example, PolygonRidges may incorporate Domes as part of their structure.

\subsubsection{PolygonRidges}

As termed by Phillips et al. (2021), PolygonRidges are the most recognizable structures in the study area (Table 2; Figure 3). They are elongate topographic features with variable surface texture and generally a maximum of a few tens of meters long (Table 2; Figures 3A,B). From above, the ridges form a honeycomb pattern (Figure 2B). They were defined as 
TABLE 1 | Mineralogical detections by different methods.

\begin{tabular}{lcccc}
\hline & XRD & Raman & IR & Petrography \\
\hline Gypsum & $\mathrm{x}$ & $\mathrm{x}$ & $\mathrm{x}$ & $\mathrm{x}$ \\
Anhydrite & - & $\mathrm{x}$ & $\mathrm{x}$ & $\mathrm{x}$ \\
Bassanite & - & - & $\mathrm{x}$ & - \\
Halite & $\mathrm{x}$ & - & - & - \\
Calcite & $\mathrm{x}$ & - & - & $\mathrm{x}$ \\
Magnetite & $\mathrm{x}$ & - & - & - \\
Plagioclase & - & - & - & $\mathrm{x}$ \\
Chromate & - & $\mathrm{x}$ & - & - \\
\hline
\end{tabular}

structures with a length to width ratio (L:W) value of $>2: 1$ and are said to be continuous when the distance between ridge segments was less than the width of the ridge, i.e., the separation was less than $\sim 2 \mathrm{~m}$. PolygonRidge crests fall into two types: intact and eroded (Figure 4). In addition to the two crest types, ridges may have rough or spiny (i.e., having extruded crystals) macroscale surface textures, or both (Figure 3C); few smooth ridges were observed. These PolygonRidges show no preferred orientation relative to the tectonic stress field as determined qualitatively from aerial photographs and digital elevation models (Figure 2).

\subsubsection{Megapolygons}

Easily seen in drone images, Megapolygons were irregularly shaped and discontinuously bounded by PolygonRidges (Table 2; Figure 2B). Their interiors were overall relatively flat but might encompass low ridges or small domes with relief of less than $1 \mathrm{~m}$.

\subsubsection{Domes}

Domes are the most characteristic features in our study area (Table 2; Figures 3A,C) They are convex-upward, quasicircular, topographic highs and are defined as structures with 1: $1<\mathrm{L}: \mathrm{W}<2: 1$ and heights that varied continuously between circa 0.1 and $2.0 \mathrm{~m}$. All domes that breached during sampling had lined convex-upward cavities below the surface gypsum layer. Most Domes had surface cracks, some of which widened into circular holes that connected the cavity to the surface (Figure 4D). The ceilings of cavities and edges of the holes were lined with an undulating layer of hard, white gypsum often with fractures and sometimes damp (i.e., moisture was present; Figure 5D). The Domes, some of which are partially collapsed, had surface textures that are either uniform or had gradual or abrupt transitions between textures (Figure 3C). Some surfaces had micropolygons, which are tiles in which the micropolygon interiors (MP Interiors) are flat and micropolygon rims (MP Rims) demarcate the margins (Table 2). These surfaces had combinations of smooth, rough, or spiny textures, which allowed further separation of Domes into sub-types (Figure 3C, Figures 5A-C).

\subsubsection{Quasi-Flat Areas}

Quasi-Flat areas have minimal positive relief and constitute the space between Domes and PolygonRidges (Figure 3A). Some surfaces comprise rimmed, irregular micropolygons lacking surface texture (smooth) or they are covered with duricrust,

TABLE 2 | Macroscale and microscale structures and textures observed in the field at Salar de Pajonales.

\begin{tabular}{|c|c|c|c|c|}
\hline Dimensions (m) & Relief (cm) & $\begin{array}{l}\text { Length to } \\
\text { width }\end{array}$ & Continuity $^{a}$ & Figure \\
\hline$<2.5$ wide & 10-200 & $>2: 1$ & $0-2$ & $3 b$ - ground view \\
\hline 10 s across & $<5$ & $\sim 1: 1$ & $0-2$ & $3 c-$ ground view \\
\hline 10s across & $<200$ & na & $0-2$ & 2 aerial view \\
\hline
\end{tabular}

Macroscale Surface Textures

\begin{tabular}{|c|c|c|c|c|c|}
\hline & Surface Relief (cm) & Maximum visible crystal size $(\mathrm{cm})$ & & Duricrust $^{b}$ & \\
\hline Smooth & $<7$ & na & & $1-2$ & $4 a$ \\
\hline Rough & $<10$ & na & & 2 & $4 b$ \\
\hline \multicolumn{6}{|l|}{ Ridge Types } \\
\hline Intact & $<200$ & na & & & $4 d$ \\
\hline Eroded & $<100$ & $15-18$ & & & $4 f$ \\
\hline MP rims & $<2 \mathrm{~cm}$ & not exposed & white, brown & $0-2$ & $5 a$ \\
\hline MP interior & $<0.5 \mathrm{~cm}$ & not exposed & white, $\tan$ & 0 & $5 a$ \\
\hline \multicolumn{6}{|l|}{ Microscale Surface Features } \\
\hline Fractures or cracks & $<20 \mathrm{~cm}$ & not fully exposed & white, gray, brown & na & $5 c$ \\
\hline \multicolumn{6}{|c|}{ Centimeter to Millimeter Scale Surface Cover } \\
\hline Duricrust, Gypcrete & $<2 \mathrm{~mm}$ & na & brown, tan & na & $6 a$ \\
\hline Bulbous, Rugosic Texture & $<2 \mathrm{~cm}$ & na & white, $\tan$ & $1-2$ & $6 b$ \\
\hline
\end{tabular}

${ }^{a} 0=$ discontinuous, 1 = continuous with gaps, 2 = continuous.

${ }^{b} \mathrm{O}=$ no duricrust, 1 = partial duricrust, 2 = completely covered with duricrust. 


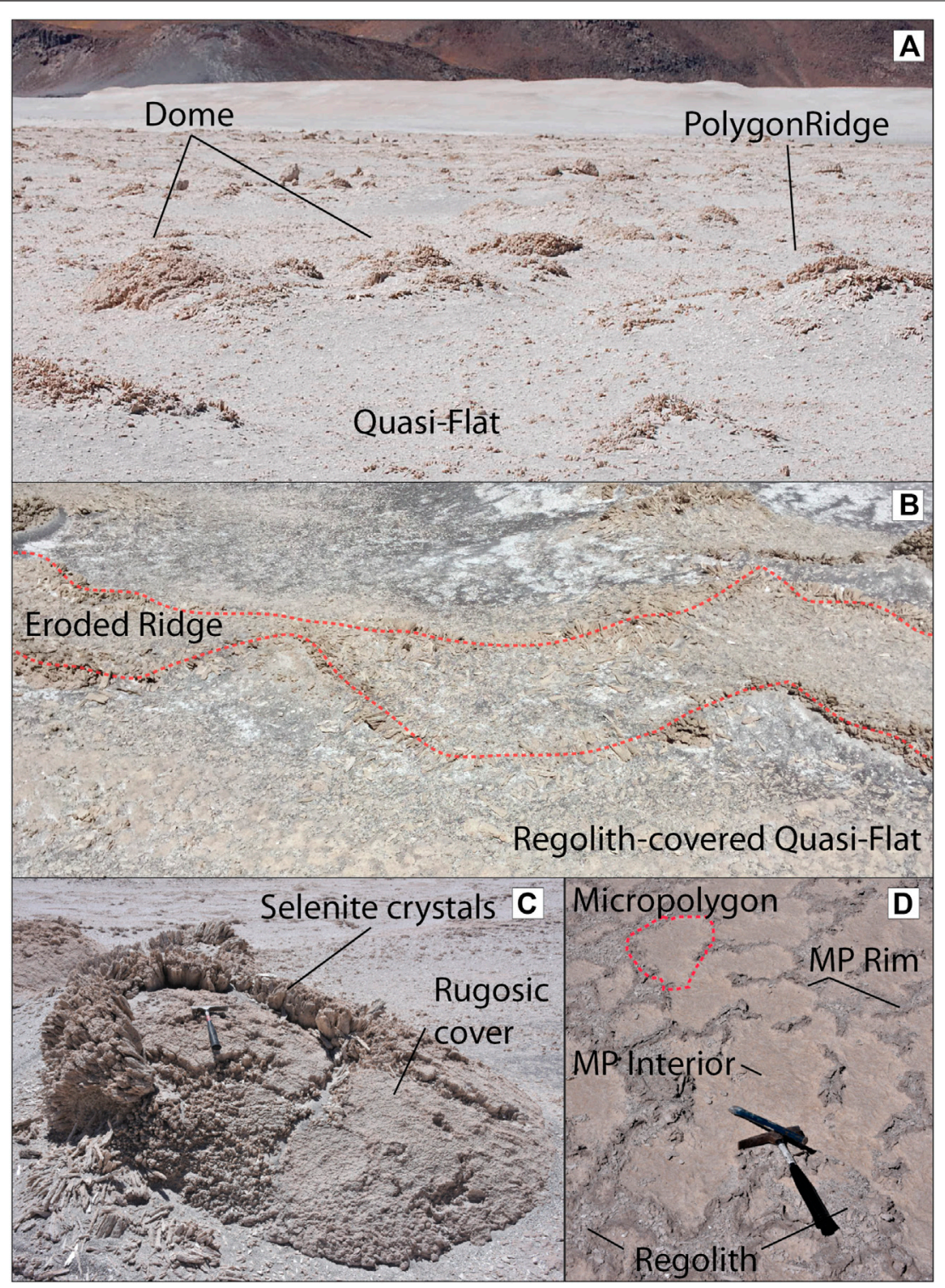

FIGURE 3 | Morphologies of PolygonRidges, Domes, and Quasi-Flats. (A) Landscape view identifying PolygonRidges, Domes, and Quasi-Flats. Field of view is ca. $12 \mathrm{~m}$ at the bottom edge. (B) Ground view of eroded PolygonRidge and regolith-covered Quasi-Flat. Dashed red line delineates eroded ridge margins. On ridge margins, selenite crystals are randomly oriented. Regolith occupies the space between the selenite crystals. Field of view is ca. 8 m. (C) Dome with rough surface and fractures. Rough surfaces had combinations of irregular micropolygons comprising MP Interiors, which are irregular tiles with diameters of 10-30 cm that are separated from each other by cracks or rims. MP Rims are narrow $(3-5 \mathrm{~cm})$ sinuous topographic highs $(<\mathrm{ca} .2 \mathrm{~cm})$. Rough surfaces had a layer of duricrust and/or bulbous (i.e., platey, rugosic, or knobby) cover. Both rough and smooth surfaces (see 3D) had fractures, which were sinuous, semi-continuous cracks that were vertically displaced up to ca. $20 \mathrm{~cm}$. Intact, growth-aligned crystals were visible on the upward-thrust side of the fractures. (D) Quasi-Flats with regolith, micropolygons, MP interiors, and MP Rims. MP interiors could be bare, hard, smooth surfaces with selenite crystals truncated across the growth plane or could be covered with regolith. MP Rims were gray/brown, cemented, sand-sized or finer material present as elongate, positive topographic features. The profile of MP Rims comprised a central, grain-filled, cm-scale-deep furrow and two parallel edges that thinned towards and blended into the MP Interiors.

bulbous material, gypcrete (strongly indurated rock comprising gypsum), and regolith (Table 2; Figure 5). Other Quasi-Flat areas lack micropolygons. These surfaces are covered with duricrust, bulbous material, gypcrete, and regolith, whereas smooth surfaces do not occur. Micropolygons had similar shapes to those present on Domes except that the MP Interiors may be smooth, and the MP Rims appear partly eroded.
3.2 Centimeter to Millimeter Scale Features Upon closer examination, some macroscale features (i.e., Domes, PolygonRidges, and Quasi-Flats; Figure 3 and Table 2) were not just distinguishable by their large-scale morphology but also by a variety of gypsum types (Figure 6).

The most common crystal habit for gypsum is fishtail twinned selenite. Twins are bottom-nucleated and originated from a 


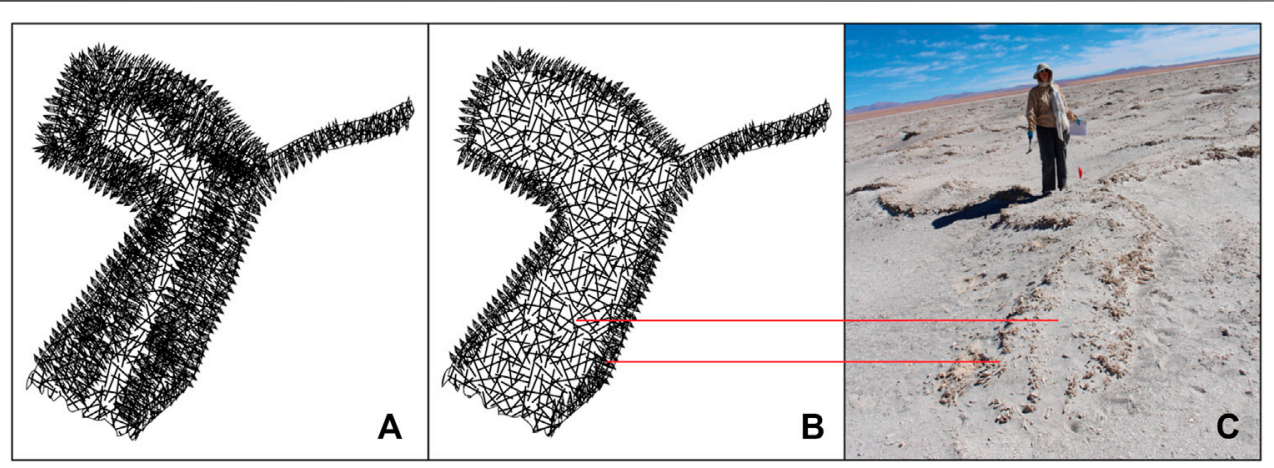

FIGURE 4 | Sketch of intact ridge (A) and eroded ridge (B). Intact ridges are short segments of upwardly convex linear structure with rough surfaces as defined for domes and with an intact surface bed (roof), and ii) eroded ridges are defined by two quasi-parallel, sinuous lines of randomly oriented spines of similar length ( $<18 \mathrm{~cm}$ ) between which are areas of mixed regolith. (C) Image of eroded ridge showing branching form. Person for scale.

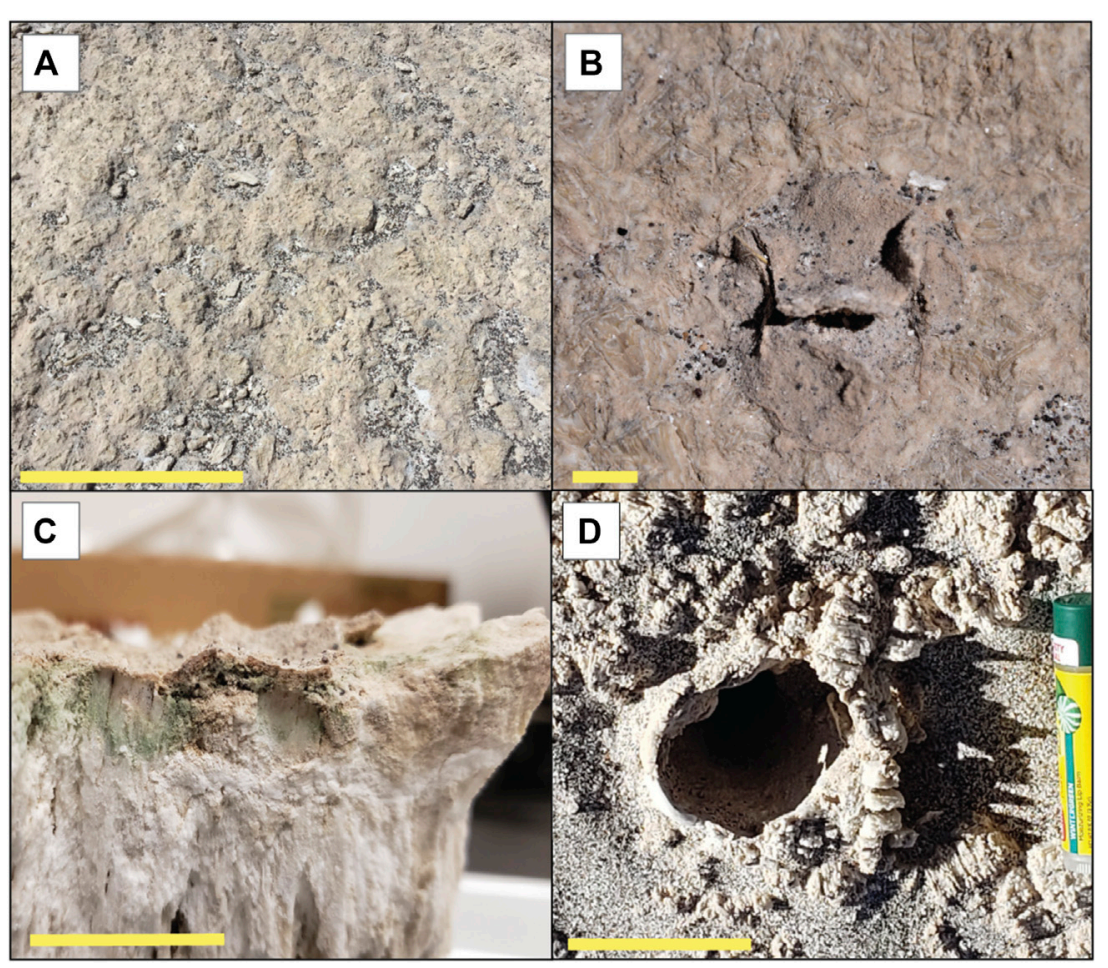

FIGURE 5 | Surface textures and holes. (A) View of rugosic texture and regolith from above. Scale bar is ca. $50 \mathrm{~cm}$. (B) Partially detached duricrust on smooth surface. Scale bar is $1 \mathrm{~cm}$. (C) Partially detached duricrust. Note pigments below duricrust. Scale bar is $1 \mathrm{~cm}$. (D) Lined hole in bulbous texture with regolith. Scale bar is $5 \mathrm{~cm}$.

horizontal, likely erosional, surface. They terminate perpendicular to the growth direction at another likely erosional surface (Figure 6A). Petrographic analysis reveals growth fronts visible in hand specimens and in thin sections of the crystals (Figure 6 and Figure 7). On spiny dome surfaces, some twinned crystals increase, while others decrease in size resulting in more crystal-nucleation sites at the base of the gypsum layer than extend through the height of the crystal layer. Selenite domains are rigid and coherent.
Alabaster is a less common habit, most often occurring at the bottom of PolygonRidges and Domes at the juncture of these structures and the salar surface but also inter-grown with selenite and filling vertical slot pores (Figures 6, 7). Alabaster was not observed in spines but could be observed associated with un-erupted crystals. When intermingled, alabaster and selenite domains were sometimes difficult to visually distinguish in the field, but the presence of alabaster could usually be determined by its physical properties. Domains 


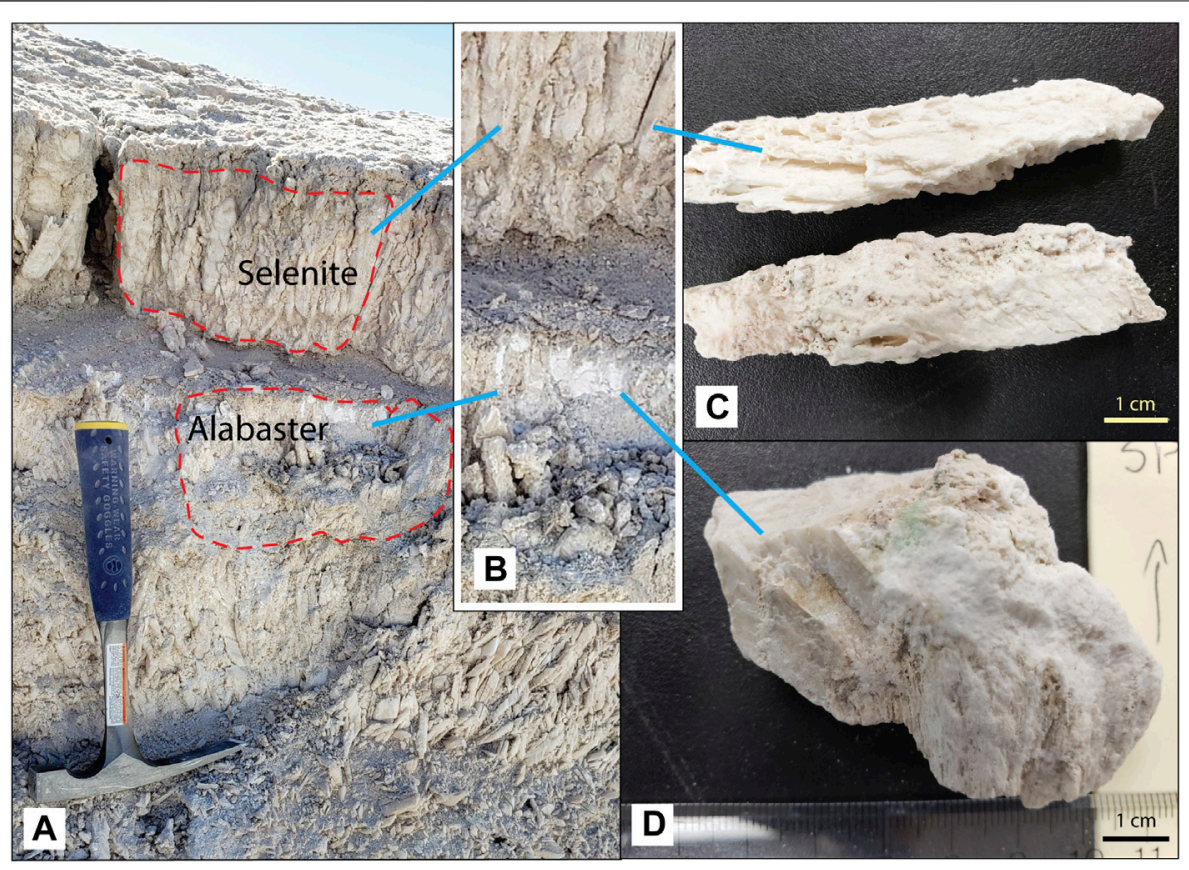

FIGURE 6 | Crystal and alabaster textures. (A) Surface bed of in-place crystals caps sediment package with alabaster domains. (B) Close up of selenite and alabaster in (A). (C) Selenite crystal. Scale bar is $1 \mathrm{~cm}$. (D) Alabaster. Arrow indicates up direction. Scale bar is $1 \mathrm{~cm}$.

dominated by alabaster were powdery and easily crumbled between fingers and yet were difficult to break with a rock hammer; the alabaster became somewhat thixotropic under hammer pressure.

Surface cover is present over both habits; duricrust, bulbous texture, rugosic (wrinkly) texture, gypcrete, or regolith is present and could form from a combination of physical (changes in temperature or hydration) and mineralogical (phase changes) as invoked here for larger structures and biological processes (Warren-Rhodes et al., in review). It likely stabilizes the alabaster surface and prevents mechanical erosion. Selenite sometimes has a surface cover (Figure 5, Figure 8). Duricrust and bulbous texture are diagnostic for the presence of alabaster (Warren-Rhodes et al., in review). Among selenite crystals, those occurring in MP Interiors or on surfaces of smooth and rough domes have duricrust, bulbous texture, rugosic texture, or gypcrete surfaces and are often denser at the surface than at depth, while erupted selenite has surface cover less frequently. Loose material, i.e., regolith, covered some of the surfaces.

Taken together, the observations across spatial scales record a history of conditions/mechanisms causing morphologies at the macroscale (Domes, PolygonRidges, Megapolygons, and QuasiFlats) and microscale (surface-cover type and selenite or alabaster crystal domains).

\section{DISCUSSION}

Our observations suggest a strong inter-dependency between small and large spatial scale features that we interpret to be controlled by extrabasinal changes in environmental conditions (e.g., relative humidity, precipitation, and temperature as controlled by climate). The environmental parameters may include precipitation-evaporation balance changes and thermal cycles and most importantly, internal processes of hydration/ dehydration, efflorescence/deliquescence, and recrystallization typical for chemical sedimentary systems.

This section first discusses the macroscale features, followed by the microscale features, the origin and timing of their formation, and lastly the implications for Mars exploration.

\subsection{Processes Controlling the Formation of Macroscale Features}

\subsubsection{PolygonRidges and Megapolygons in Salars}

PolygonRidges as geomorphic features can form through a wide variety of geologic processes, including warping due to pressure or shrinkage caused by tectonic or other processes, during deposition, and as remnants of erosion. The gypsum ridges in the salar are part of a polygonal network that enclosed Megapolygons without any aligned distribution (Figure 2B). All PolygonRidges were about the same height. We attribute this to ongoing constructional processes in the salar that exceed erosion rates.

Tectonic and volcanic processes in the actively uplifting Cordillera are constantly at play. However, the dominant regional structures related to the ongoing tectonic shortening and uplift are oriented in a NE-SW and NW-SE direction (Figures 1B,C), whereas the polygonal patterns are not aligned. The Dome Field itself is aligned with a series of 


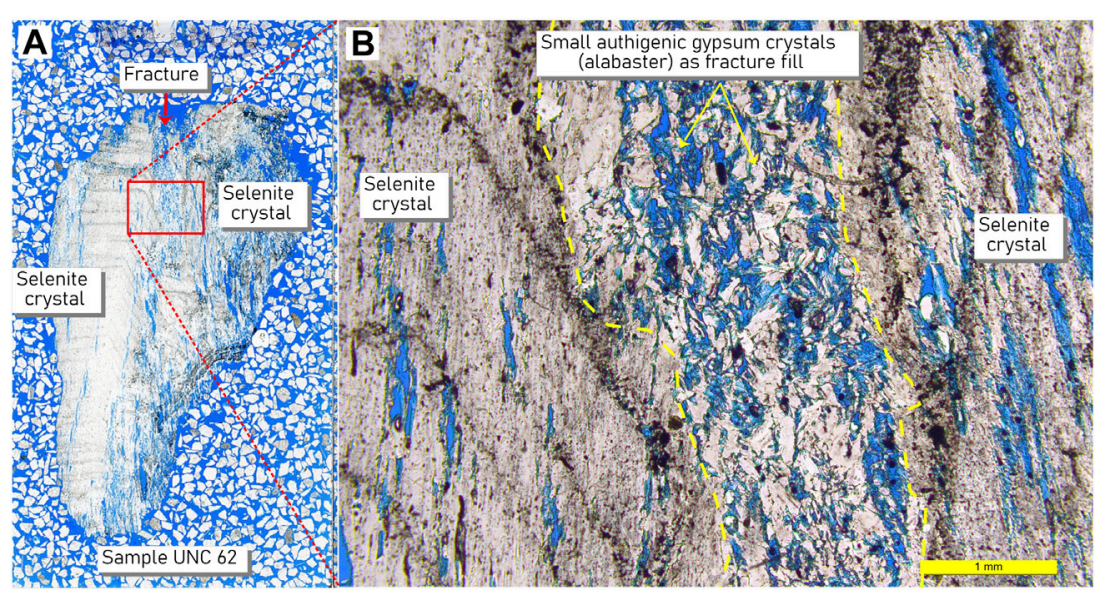

FIGURE 7 | Petrographic thin section showing growth fronts in selenite crystal habit. (A) Scan of petrographic thin section. (B) Close-up of area within red box in A. Selenite crystal with growth fronts and small patches of alabaster with slot pores. Such growth fronts were $\leq 2 \mathrm{~mm}$ thick and comprised an opaque black layer separating layers of selenite gypsum. Pores can be filled with intraclastic gypsum grains, secondary gypsum crystals, and/or volcanic detritus and may be adjacent to alabaster domains. Slide background is a mixture of mineral grains to show slide thickness during preparation.

cinder cones that are strung along the direction of one of the main regional structural grains (Figure 1). However, tectonic forces act on long timescales, and a degradation of ridge axes would be expected to reflect their erosion between tectonic events, contrary to the observed roughness on the ridges and overall high topographic relief. Although some PolygonRidges were over $100 \mathrm{~m}$ long, most measured tens of meters in length but maintained an overall consistent height. Tectonic ridges that comprise fault scarps related to regional forces would be expected to have lateral continuity of hundreds of meters and kilometers with heights that scale to the length and taper towards the tip of the faults. No such continuity is observed on the relatively local scale of the ridges in the Dome Field, and we do not attribute the PolygonRidges to tectonic forces.

Instead, we propose the PolygonRidges in the Dome Field reflect intrabasinal volume changes associated with wetting and drying cycles, i.e., hydration-dehydration or recrystallization cycles, along with increases in salt volume during transport and evaporation of saturated brines. Figure 9 illustrates gypsum-specific processes based on Warren's (2016) model for ridge formation in evaporites; a model we propose is largely apropos to ridge formation in the salar. The original salar surface formed during a time of inundation, has become exposed, and has since been flattened by mechanical and chemical weathering (Figure 9A). Chemical weathering occurs in subsequent rain events during which selenite crystals dissolve and recrystallize into a dense gypsum surface layer (Figure 6A). Such horizons in the subsurface can undergo extensive dissolution and reprecipitation, as water chemistry changes, with associated volume changes over time (Figure 9B). These horizons can promote lateral water flow and additional salt dissolution to destabilize the salar surface, which leads to the PolygonRidges. The spacing of the ridges would depend on the amount of water flow, and therefore destabilization, in the subsurface; more water flow in the subsurface (volume or frequency) would lead to more closely spaced ridges, i.e., smaller Megapolygons.

\subsubsection{Domes in Salars}

Domical structures within an evaporite basin can form by several processes that largely hinge on volume changes associated with wetting and drying cycles, with an associated change in salt volume during dilution and evaporation of saturated brines.

Domes are common features in gypsum evaporites (Warren, 2016). Their origin is most often attributed to volume changes associated with recrystallization brought on by cycles of hydration-dehydration reactions. The details of this process vary. Artieda (2013) suggests that after in situ dissolution and precipitation events, secondary gypsum fills pores, increasing volume and pressure, leading to lateral gypsum expansion to form domes, called "tumuli." Calaforra and Pulidobosch (1997) offer the alternative that the volume increase is caused by recrystallization from anhydrite to gypsum. They agree with Artieda (2013) that infilling the gypsum matrix within macrocrystalline gypsum could also cause the volume to increase. Gutiérrez (2005) suggests that tumuli may form from changes in volume due to wetting and drying of a thin layer below the surface gypsum bed, which Warren (2016) attributes to efflorescence within the surface bed. We propose a very similar genesis-i.e., the result of volume changes in the evaporites during multiple hydration cycles-for the formation of the domes in the salar. This leads to warping of the salar surface.

Warping only affects the uppermost gypsum bed giving clear evidence for a control associated with surface processes, rather than deep-rooted tectonic forces. Textural transitions also occur on the sub-centimeter scale. As a result, we agree with Warren (2016) and attribute the presence of alabaster in the proximity of or filling small cracks in the deformed selenite crust to efflorescence (Figure 7B). Efflorescence involves the precipitation of salt from brine. The brine is transported as 


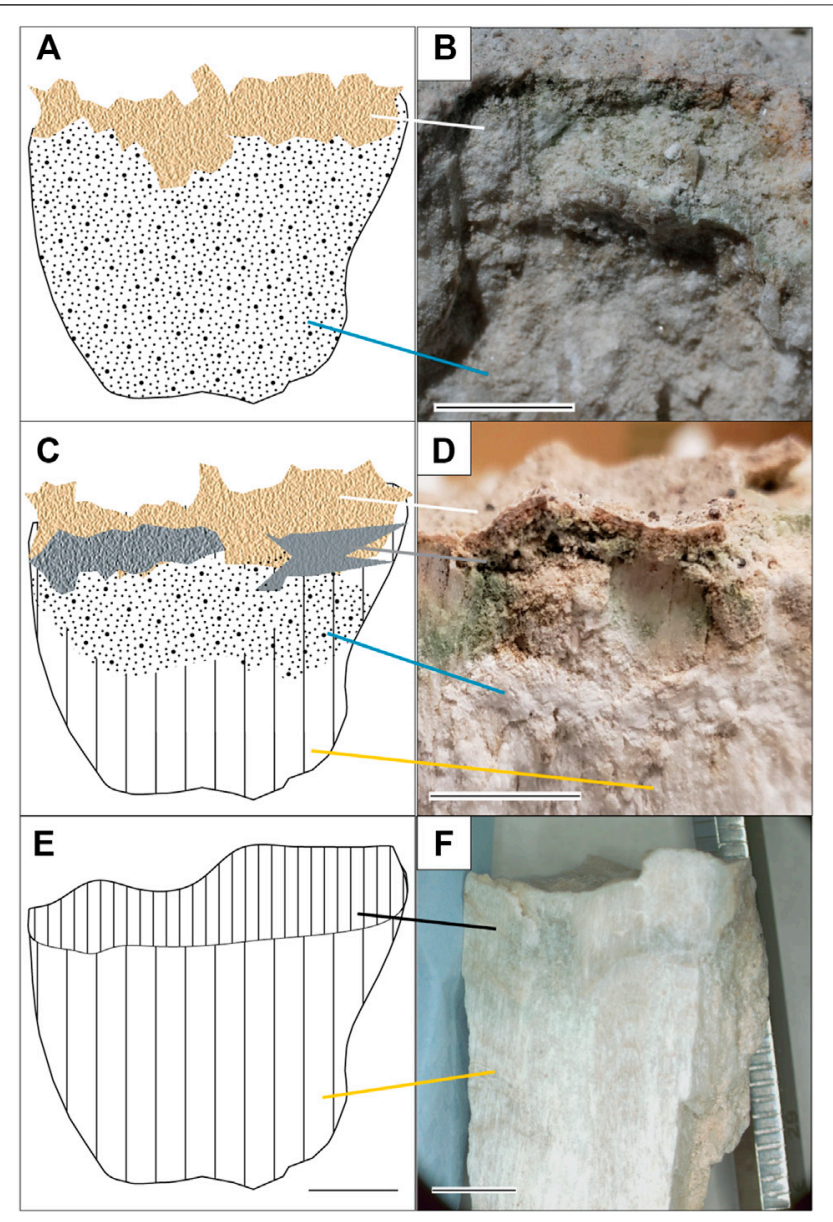

FIGURE $\mathbf{8}$ | Surface textures on gypsum. (A) Duricrust comprises a tan crust (white line) that overlies and is fully attached to the alabaster gypsum surface (blue line). Gypsum may have either selenite or alabaster habit, but alabaster is used here to match the image. Scale bar for $(\mathbf{A}, \mathbf{C}, \mathbf{E})$ is ca.

$1 \mathrm{~cm}$. (B) Image of duricrust. Scale bar is $1 \mathrm{~cm}$. (C) Bulbous texture comprises detached duricrust (white line) over the gypsum surface, which is drawn here as alabaster (blue line) above selenite (yellow lone) to match the example. Gray line connects void space beneath the detached crust. Duricrust and bulbous texture are diagnostic for the presence of alabaster (Warren-Rhodes et al., in review). (D) Image of duricrust and bulbous texture. Scale bar is $1 \mathrm{~cm}$. (E) Gypcrete comprises a denser selenite texture (black line) where pore space has been filled with secondary gypsum. Gypcrete overlies selenite (yellow line). (F) Image of gypcrete. Scale bar is $1 \mathrm{~cm}$.

salt-saturated vapor until it condenses in pores. When conditions become warmer or dryer, the water evaporates again, leaving the salt behind to increase the mineral volume. The presence of anhydrite remnants in some of our samples suggests episodic complete dehydration of the Ca-sulfate phase. The decrease in volume associated with the dehydration (recrystallization to anhydrite) and increase in volume with subsequent hydration (recrystallization to gypsum) is another process we consider as a mechanism for dome formation. These processes could be aided by accompanying changes in brine chemistry brought about by changes in volcanic activity and groundwater recharge. Consequently, a water-related process, one with multiple episodes of wetting and drying, is the most reasonable explanation for the formation of tumuli in the salar, an explanation in line with the formation processes proposed for similarly sized tumuli elsewhere (Gutiérrez and Cooper, 2013). Holes, interpreted to be gas vents lie within two larger gas domes and provide individual sites for water vapor and gas exchange leading to focused warping to form Domes (Hofmann et al., in review).

\subsubsection{Quasi-Flat Areas in Salars}

Quasi-Flat areas had surface characteristics different from Domes and PolygonRidges except for the presence of polygonal features, which could be found on Domes. Rims separate MP Interiors on the solid, quasi-flat salar surface. The arrangement of the MP Interiors and rims forms the "patterned ground" referenced in Phillips et al. (2021) and Warren-Rhodes et al. (in review).

The MP Interiors and MP Rims (Table 2) may have formed during wetter times if thin microbial mats had covered the surface of the shallow salar. Wetting and drying cycles may contribute to both abiotic and biological processes during which a thin surface layer experiences cycles of hydration and

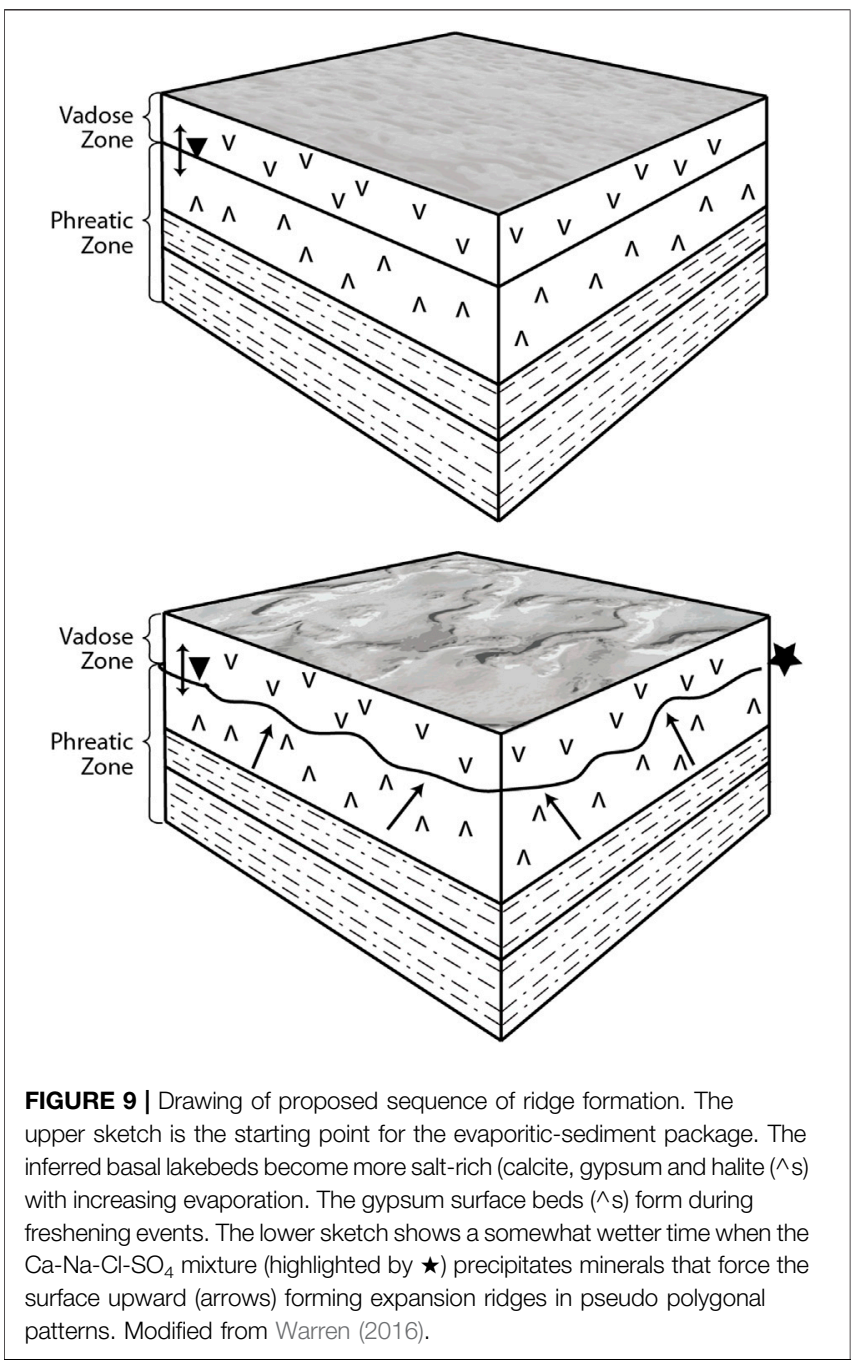


dehydration, leading to development of rims around polygonal tiles, called tepees (mainly abiotic origin) or petees (mainly biotic origin) (Noffke, 2010; Warren, 2016). In the Dome Field, elevated micropolygon margins and shrinkage cracks are both present, forming irregular rims of sand-sized and finer particles bound together by tan to gray gypsum cement. The sometimes smooth, interior flat surfaces may crack secondarily into shrinkage structures, exposing the barren deposits beneath. Both the surfaces of the micropolygons and MP Rims have been abraded by wind and degraded by episodic rain events during which water pools in MP Interiors and infiltrates preferentially into rims (Warren-Rhodes et al., in review). Although our data do not yet allow us to determine the biogenic or abiotic origin of these flats and micropolygons, the laminae size, occurrence of microbial layers, and the substrate composition (gypsum) suggest that physical processes might play the primary role while biologic processes might be secondary and may serve to exaggerate the physically induced micro-morphology.

There are alternative explanations for the formation of micropolygons. Artieda et al. (2015) report different types of halite polygonal structures in Salar Grande and Yungay basins and attribute the differences to an evolutionary process whereby regular, flat polygons transform first into well-developed tepees with open, axial troughs and then into nodular, heavily uplifted, highly deformed, fin-like near vertical structures with distinct internal zonation. Deliquescence serves to enrich the salt content along the margins of the polygons and increasing the height of the rims (Artieda et al., 2015). These structures appear to require deliquescent salts and limited precipitation and would be incompatible with the much less soluble Ca-sulfate matrix, although we cannot rule out that other salts played some role. Nevertheless, the structures observed at the Dome Field do not require such processes.

\subsection{Centimeter and Millimeter Scale Features}

Mineralogical transformations between gypsum, the dominant mineral, and its dehydrated form, anhydrite involve a 39\% change in volume (Jowett et al., 1993); gypsum dehydrates to the denser anhydrite leading to slot pore formation on a millimeter scale and surface-crack formation and structural collapse on a centimeter to meter scale. Cracks then enable water transport leading to rehydration of anhydrite to gypsum. These dehydrationrehydration cycles lead to expansion and contraction of the salar surface (Charola et al., 2007). In addition, salts accumulate at the surface by efflorescence, increasing the volume of solids at the surface. Associated deliquescence results in a decrease in volume of solids at the salar surface. All three processes-recrystallization, dehydration-hydration, and efflorescence - are probably at work, and all three point to the role of water, and therefore climate, on the surface morphology.

Changes in mineral habit affect porosity (Yilmaz and Karacan, 2005) and thus the ability of the gypsum materials to transport water (Koponen et al., 1997). Thus, the more porous alabaster has

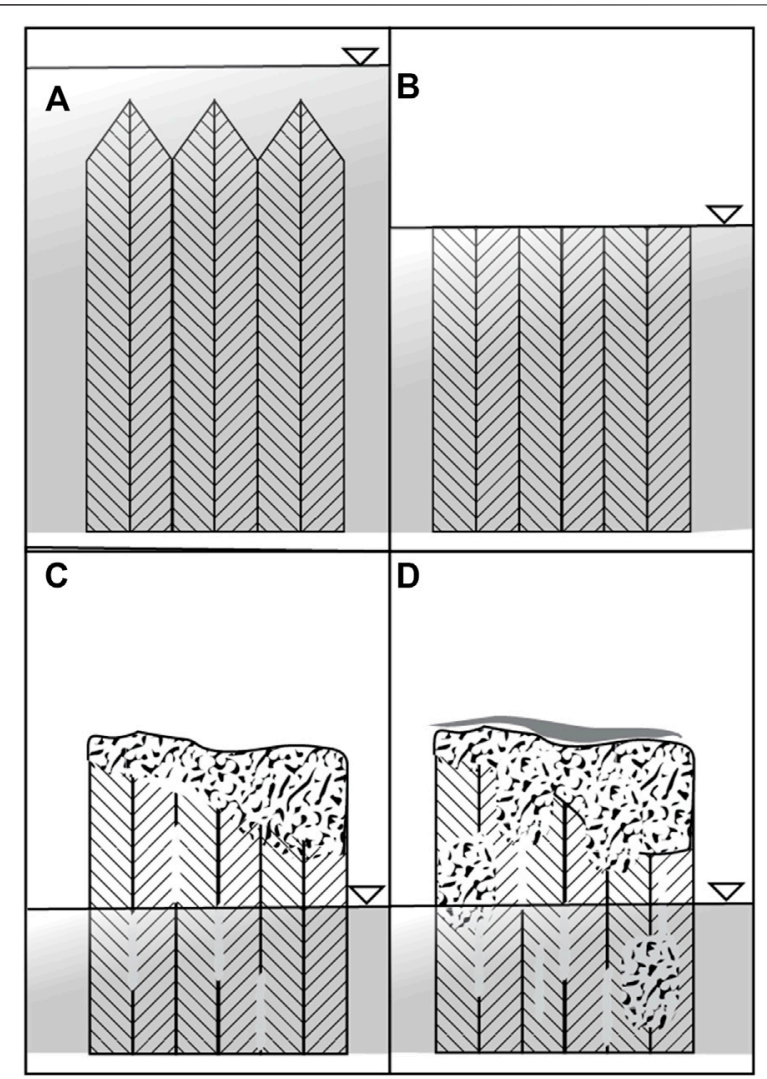

FIGURE 10 | Scenario for textural changes in gypsum at the salar surface caused by climate change, which is depicted as a change in water table elevation and the thickness of the saturated zone (shaded area). (A) Bottom-nucleated selenite forms on the bed of a shallow saline lake. (B) The surface is eroded during arid times. Changes in the water table lead to variable saturation and salt transport in vadose zone. (C) Surface crust and slot pores develop. (D) Additional alabaster zones develop further enhancing water availability.

greater permeability than does less porous selenite. The sequence of wetting and drying cycles leads to the current distribution of selenite and alabaster habits (Figure 10). In the initial stages, bottom-nucleated selenite formed on the bed of a shallow saline lake during freshening events. During more arid times, the surface would be eroded. Climate could drive changes in the water table, which, along with surface precipitation, could cause variations in the depth and saturation of the vadose zone. Temperature could also play a role. Meteoric water could infiltrate and freeze in the surface layer as temperature decreases (Warren-Rhodes et al., in review). The associated volume changes could lead to formation of slot pores further enhancing water transport and retention.

Quasi-Flat areas and Domes have either smooth surfaces or low relief covers of duricrust, bulbous cover, or gypcrete. Duricrust forms during lithification of biological soil crust, by physical deposition processes (Davis et al., 2010) or by capillary migration and evaporation of soil water (Wierzchos et al., 2011). At the Dome Field, there is ample evidence microbial communities populate the shallow subsurface even under 
today's hyperarid conditions (Warren-Rhodes et al., in review). We can infer that, during wetter times, microbial mats may have covered the salar surface as they do in other saline environments (Des Marais, 2010; Noffke, 2010). The EPS from the mat would have bound detrital grains from volcanic and local sources (Noffke, 2010) and been in contact with salt-saturated solutions, either halite or gypsum, depending on the degree of concentration. Gypsum-saturated solutions would infuse the microbial mat and serve to lithify the EPS prior to saturation with respect to halite. The detritus-bearing surface layer points toward the relevance of EPS mineralization as a process for forming duricrust at the Dome Field. However Wierzchos et al.'s (2011), model describes duricrust formation in systems saturated with respect to halite, which is much more soluble than gypsum. Warren-Rhodes et al.'s (in review) model promotes capillary migration as a cause for the formation of a denser gypsum surface layer, i.e., gypcrete, but does not mention formation of duricrust. Efflorescence also has a role in shaping the salar surface. As a potential cause for dome formation (Warren, 2016), efflorescence may contribute to the formation of gypcrete and bulbous cover by transporting salt-saturated solutions to the surface where they deposit Ca-sulfate minerals and change the texture and rigidity of the surface horizon. Bulbous cover likely evolves over time as fresh water from precipitation events seeps into slot pores leading to recrystallization from selenite to alabaster. Over time, the surface becomes knobby, and such knobs would indicate where alabaster would be found (Warren-Rhodes et al., in review).

\subsection{Origin and Evolution of Surface Forms - The Role of Water}

The surface structures and textures at the Dome Field record a history of hydrological changes that affect the mineralogy and volume of Ca-sulfate in beds that comprise the salar surface and are visible as paleoterraces (Figures 2C,E). Several mechanisms for surface structure formation are presented in Table 3. The most likely scenarios involve water-related processes.

Changes in groundwater lead to Megapolygon-defining surface ridges due to expansion and contraction in response to mineral precipitation. Cycles of wetting and drying accompanied by vapor exchange in vents or salt cones lead to focused warping of the surface Ca-sulfate bed to form Domes, i.e., tumuli. Water ponds in Quasi-Flat areas lead to smaller polygonal patterns of tepees, petees, and shrinkage cracks. In the course of their formation, mineralogical transformation and recrystallization affect the texture and porosity of the surface material. The transition from primary selenite crystals to secondary alabaster is accompanied by a change in porosity that would enable water transport. Indeed, water is the driving factor in the distribution of photosynthetic life among all macro- and micro-scale structures at Pajonales (Warren-Rhodes et al., in review). Evidence of this selenite-to-alabaster transition takes the form of surface textures: duricrust, bulbous cover, and gypcrete are indicators of selenite-alabaster transitions. These climate-related changes in hydrological conditions are evident at the macro to microscale at the Dome Field.
The timing of formation remains uncertain. It is not entirely clear whether PolygonRidges and Domes are contemporaneous. One observation would suggest that the PolygonRidges predate the Domes: intact ridges are rare and most are eroded, unlike domes for which a substantial number are intact. Most of the ridges have collapsed, which suggests loss of structural integrity and eroded to axial deposits of intraclastic selenite detritus and regolith (Figure 4). It is possible that this collapse is linked to climate-related, watertable-elevation cycles, which caused dissolution of salt or hydration and dehydration of mixed chloride-sulfate salts in the subsurface (Bishop et al., 2021) that led to volume changes and destabilization of the surface (Figure 9). This would lead to linear features creating quasi-tiles, such as, PolygonRidges and Megapolygons. In contrast, more local focii would lead to circular features, like Domes, which would accommodate the volume changes from a central point rather than from a landscape-scale pressure field. This would suggest that the PolygonRidges represent longer-term processes, which would explain their degraded condition. An alternative observation is that Domes have a shape with more structural integrity than do PolygonRidges and therefore, would not rule out contemporaneous formation and must be considered, along with genetic mechanisms.

\subsection{Implications for Mars Exploration}

Salar de Pajonales is an excellent analog for evaporitic basins on Mars because of its high UV radiation, relatively thin atmosphere, broad diurnal and annual temperature variations, volcanic and hydrothermal activity, mineralogy, morphology, geomorphology, salt abundance, and aridity (Cabrol et al., 2001; Bada et al., 2003; McKay et al., 2003; Wettergreen et al., 2005; Grunthaner et al., 2006; Warren-Rhodes et al., 2007a; Warren-Rhodes et al., 2007b; Cabrol et al., 2007; Piatek et al., 2007; Gómez-Silva et al., 2008; Cabrol et al., 2010; Cabrol and Grin, 2010; Fairen et al., 2010; Fiahaut et al., 2017; Cabrol et al., 2018; Wilhelm et al., 2018). Our evidence suggests that repeated wetting and drying cycles are responsible for the geomorphic and petrographic characteristics of surface structures at the Dome Field.

PolygonRidges and Domes are topographic modifications caused by wetting and drying of Ca-sulfate salts on the existing salar surface and in the subsurface. The effects of water on the volume changes in Ca-sulfate minerals, coupled with the ability of gypsum to form indurated beds, may be key to the formation of these macroscale surface structures (Domes, in particular); we are not aware of any occurrences of Domes in exposed evaporite beds dominated by minerals other than gypsum. Changes on the microscale are equally important. Specifically, the changes in porosity and pore structure signal the effects of water on the habit, texture, and mineralogy of the gypsum beds. Pores isolated by reprecipitation, efflorescence, or mechanical closure might serve as micro-reservoirs. Consequently, it may be possible that gypsum evaporite beds and structures could retain water in pore spaces or along crystal surfaces despite overall salar desiccation. Thus Ca-sulfate surface structures could pinpoint evidence of water-related processes and mimic surface patterns_-"patterned ground" or "polygonal 
TABLE 3 | Possible mechanisms for formation of the macroscale features.

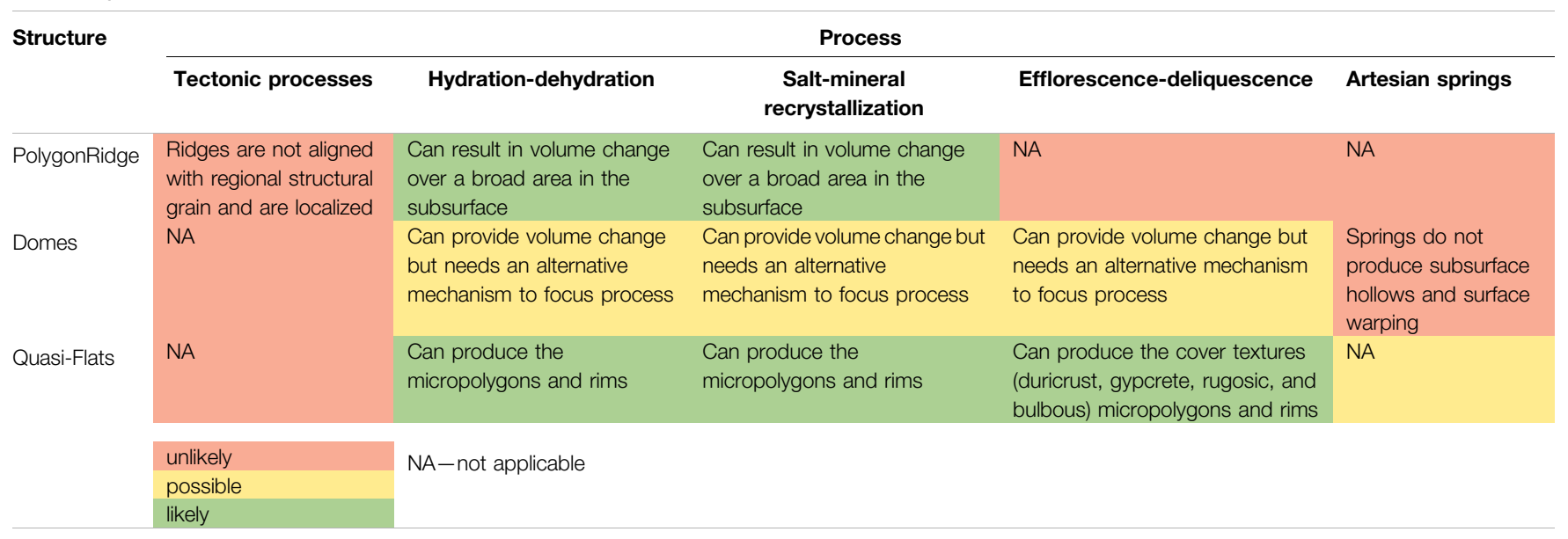

networks" - at mid-to higher latitudes on the Martian surface (Malin and Edgett, 2000; Mangold et al., 2004; Langsdorf and Britt, 2005; Mangold, 2005; Levy et al., 2009). Such polygonal patterned ground manifests itself at two scales at Salar de Pajonales-Megapolygons (tens of meters) and micropolygons (tens of centimeters), which represent the combined effects of polyextreme conditions on salar materials at different spatial and temporal scales.

Terrestrial polygons formed by desiccation processes in playa environments can range from diameters of centimeters (micropolygons) to up to $300 \mathrm{~m}$ (megapolygons) (Neal et al., 1968; Brooker et al., 2018). The larger polygons are thought to form by periods of intense evaporation due to increased aridity, combined with lowering of the ground-water table (Neal et al., 1968; El-Maarry et al., 2014; Brooker et al., 2018). Polygonal surface patterns (patterned ground) on Mars range in diameter from meters to tens of kilometers and, like terrestrial polygons, can form by several different processes and reflect a variety of past climatic conditions (Pechmann, 1980; Seibert and Kargel, 2001; Mangold, 2005; Soare et al., 2005; Morgenstern et al., 2007; Soare et al., 2008; Lefort et al., 2009; Levy et al., 2009).

The polygonal surface patterns documented to date on Mars are fairly young $(\sim 0.1-1 \mathrm{Ma})$ and, at low latitudes, have been attributed to thermal cracking (Levy et al., 2009) or, at high latitudes, to freeze-thaw cycles (Malin and Edgett, 2000; Mangold et al., 2004; Langsdorf and Britt, 2005; Mangold, 2005). In their model for low-latitude patterned ground, Levy et al. (2009) propose that cracks form through thermal expansion and contraction of subsurface ice. Ridges form along margins of the cracks leading to the observed polygonal patterns. But such ridges could form by hydrochemical processes as well. An alternative explanation for ridges on Mars may be destabilization of hydrated salts in the subsurface. Bishop et al. (2021) proposed such a model for recurring slope lineae (RSL). In their model, RSL occur as a consequence of seasonal hydration and dehydration of subsurface chloride-sulfate salts leading to slope failure. Ridge formation by a similar process, but over a longer time scale, may be occurring at Salar de Pajonales and would reflect changes in groundwater level (i.e., water table). Elevation changes in the water table could be attributed to changes in groundwater recharge and therefore to climate. Thus, it's possible the megapolygon-scale patterned ground illustrates salt-related expansion and contraction in the subsurface as a function of changes in the elevation of the water table. Similar changes in groundwater may have been common during the Noachian/Hesperian transition on Mars and contributed to the formation of patterned ground.

While PolygonRidge formation reflects changes in the subsurface (tens to hundreds of meters), Dome formation points to wetting and drying cycles at shallower depths (meters to tens of meters). On Mars, volume changes associated with recrystallization, hydration and dehydration, and efflorescence-deliquescence processes could create or modify porosity pathways for water-exchange in the shallow subsurface. Evidence for efflorescence-deliquescence transitions for chlorate salts (Fernanders et al., 2022) supports proposed occurrence of deliquescence on Mars (e.g., Pál and Kereszturi, 2020; NazariSharabian et al., 2020 and references therein). Water exchanged in this manner may point towards oases for life during the last stages of dehydration (Davila and Schulze-Makuch, 2016). Dundas and Mcewen (2010) interpreted mounds observed in Mars Reconnaissance Orbiter (MRO) High Resolution Imaging Science Experiment (HiRISE) camera images as pingos, which are mounds created by over-pressured groundwater that freezes beneath an impermeable layer, usually frozen ground (Angel de Pablo and Komatsu, 2009; Burr et al., 2009). Angel de Pablo and Komatsu (2009) attribute similar structures in the Utopia basin on Mars to pingos as well. On Earth, pingo ponds are often associated with depressions formed after the ice core melts, but pingos in their initial phase are mounds that formed during pressurization of groundwater in the subsurface (Burr et al., 2009). Volume changes in sulfate salts could occur not as a consequence of freezing but rather of changes in water content in Ca-sulfate systems (Warren, 2016). The resulting tumuli occur as tumuli fields, of which the Dome Field is an example. This provides an alternative explanation for the formation of mounds on Mars; one in which an impermeable surface layer is pushed upwards by the force of 
mineral transformation, rather than freeze-thaw, processes over time.

Desiccation polygons have been identified at the centimeter scale on the floor of Gale Crater using data from the Mars Science Laboratory (MSL) Curiosity rover (Stein et al., 2018) as well as by both MER Spirit and Opportunity rovers. In Gale Crater, ChemCam Laser Induced Breakdown Spectrometer (LIBS) and Alpha-Particle X-Ray Spectrometer (APXS), identified parallel bedding seams of $\mathrm{Ca}$-sulfate $\left(\mathrm{CaSO}_{4}\right)$ running through a gray sandstone unit which is overlain by a $\sim 1 \mathrm{~cm}$ thick red mudstone unit (Stein et al., 2018). $\mathrm{CaSO}_{4}$ veins run through most of the polygonal ridges and sometimes cut across them. In addition, sulfate-mineralized fractures are present throughout the region and are attributed to hydraulic fracturing (Grotzinger et al., 2014; Caswell and Milliken, 2017; Young and Chan, 2017). The eventual transformation of desiccation cracks into ridges likely formed by persistent flows of sulfaterich waters through the cracks and eventually formed the ridges. The discovery of these desiccation polygons in Gale Crater suggests a history of oscillating lake levels, which confirms the existence of a paleolake that rose and fell dramatically over time (Stein et al., 2018).

Gulick et al. (2019) studied the gullies and landforms surrounding the central peak of Lyot Crater $(\sim 220 \mathrm{~km}$ in diameter), which is located on the edge of the Northern Lowlands of Mars $\left(50.4^{\circ} \mathrm{N}\right.$ and $\left.29.3^{\circ} \mathrm{E}\right)$. The crater floor located just to the west of the central peak region marks the lowest elevation $(-7,034 \mathrm{~m})$ in the northern hemisphere $\left(50.6030^{\circ} \mathrm{N}, 29.16503^{\circ} \mathrm{E}\right.$ ) (Gulick et al., 2019). It is also the youngest major impact basin on Mars (Amazonian age, $<3 \mathrm{Ga}$; Greeley and Guest, 1987; Tanaka et al., 2014). In their study, Gulick et al. (2019) mapped the gullies and landforms in this region. They identified two scales of polygonal landforms, numerous depressions connected by a system of channel forms that trended downslope, a pristine-appearing 200-m diameter impact crater with lobate ejecta, gullies on the western slope of the central peak, and evidence for a paleolake just west of the central peak region. Because the central peak region would reflect the last vestiges of hydrothermal activity of this large impact crater, the adjacent paleolake likely experienced evaporation similar to Salar de Pajonales. Because current temperatures and pressures are consistent with a climate where liquid water could flow seasonally if present, Gulick et al. (2019) concluded that Lyot's central peak and paleolake region likely provided a unique microclimate where westerly winds blowing across the paleolake deposited water vapor to the central peak's western slopes. Seasonal and hydrothermally induced snowmelt on the slopes could eventually have formed the gullies. As this local hydrological cycle ebbed due to decreasing hydrothermal activity, this region would have formed an evaporative basin similar to that of Salar de Pajonales.

A follow up study by Glines and Gulick (in review) included a more detailed mapping study of the features and landforms in this region of Lyot Crater floor. In additional to several other features, they characterized the two types of polygons. The first being the low-centered dark-toned polygons with prominent raised ridges, which are up to $\sim 10 \mathrm{~m}$ in diameter and are located downslope of the system of depressions and channels. The second type are fractures outlining extensive high-centered polygons $\sim 500-1,000 \mathrm{~m}$ in diameter located in light-toned regions. These are located southeast of the central peak region and were mapped in the original Gulick et al. (2019) study. Although, HiRISE would not have resolved the $\mathrm{cm}$-scale polygons identified in Salar de Pajonales, polygons were identified down to the HiRISE meter-scale spatial resolution. Surface exploration of this young, low elevation region might reveal additional smaller scale features similar to those identified in Salar de Pajonales.

El-Maarry et al. (2014) completed a systematic study of potential desiccation polygons (PDPs) from orbit using images from the HiRISE camera. They found that PDPs tend to be located in regional depressions such as impact craters or flat plains and are associated with light-toned phyllosilicate-rich terrains. PDPs observed from orbit range from 1- to $30-\mathrm{m}$ wide, although those observed at the surface by all three rovers are centimeter scale. El-Maarry et al. (2014) pointed out that the size range may reflect variable hydrological conditions where the smaller polygons observed at the rover scale may have formed through surface evaporation while the larger PDPs may suggest fluctuating water tables like what is proposed in this paper for Salar de Pajonales.

Based on our results, surface manifestations, such as domes and polygons, of salt-related processes on Mars could point to potential water sources. Because hygroscopic salts have been invoked as sources of localized, transient water sufficient to support terrestrial life (Davila et al., 2010; Hallsworth, 2020), areas displaying such structures would be good targets for biosignature exploration on Mars.

\subsection{Summary and Future Directions}

The Salar de Pajonales is currently in a desiccation period of a series of wetting and drying cycles. The salar surface types-lagoons, salt crusts, infrequently inundated areas, and dry exposed paleoterraces (Chong Diaz et al., 2020)- spatially reflect climate changes that partly mirror similar climate transitions postulated for early Mars. These intermittently moist areas offer a glimpse into the possible last microbial refugia on Mars as the climate changed and water vanished from the surface (Davila and Schulze-Makuch et al., 2016).

Different salar surface types offer opportunities to follow morphological transformations that create distinct environmental conditions for life. These morphologies could reflect similar hydrological conditions during the wetter climate of early Mars. Focusing on the Dome Field, an exposed paleoterrace, we identified surface structures that can be identified by drone imagery (Phillips et al., 2021) and explored for different textural surfaces as defined by distinct physical, chemical, and hydrological conditions.

The Dome Field comprises gypsum deposits that infer a cyclic deposition of thin beds comprising well-developed gypsum crystals inter-layered with thinner beds of gypsum breccia and laminar sediments (Figure 2). Surface characteristics fall into two distinct groups based on spatial scale. Macroscale structures (meter-scale; PolygonRidges, which encircle Megapolygons; Domes; and Quasi-Flats) formed by volume changes associated with water-related processes, and microscale 
structures, which are attributed to water-brine-related processes active within the upper gypsum bed. Our observations suggest a strong inter-dependency between these structures across scales that we interpret to represent changes in environmental parameters related to changing climate.

Polygonal surface patterns on Mars have a bimodal size range similar to what we observe at Salar de Pajonales. At Salar de Pajonales, we attribute these changes to hydrological conditions where smaller scale polygons observed at the rover scale may have formed through surface evaporation, and larger potential desiccation polygons may suggest groundwater fluctuations. Thus domes and polygons on Mars could represent potential water sources and, hence, brine transport, creating excellent targets for biosignature exploration on Mars.

This research is part of a larger effort to determine remotesensing thresholds of detection for the surface structures described here (Phillips et al., 2021 in prep), to establish the distribution and predictability of biosignatures within the salar (Warren-Rhodes et al., in review), and to test the hypothesis of underlying unique geologic conditions in the Dome Field (Hofmann et al., in review). Consequently, we focused on the Dome Field where both the structures and the biosignatures are present. However, a complete study of the facies distribution in the Dome Field and across the larger Salar de Pajonales evaporitic basin could provide further context for the geologic and climatic controls on the observed structures and would further help to strengthen the site as a Martian analog. In this study and the accompanying papers mentioned above, our focus is on a smaller area to provide a more detailed picture of the interrelationships of structure, life, and water and our ability to detect relevant targets.

\section{DATA AVAILABILITY STATEMENT}

The original contributions presented in the study are included in the article/Supplementary Material, further inquiries can be directed to the corresponding author.

\section{REFERENCES}

Albarracín, V. H., Kurth, D., Ordoñez, O. F., Belfiore, C., Luccini, E., Salum, G. M., et al. (2015). High-up: A Remote Reservoir of Microbial Extremophiles in Central Andean Wetlands. Front. Microbiol. 6, 1404. doi:10.3389/fmicb.2015.01404

Alonso, R. N., and Rojas, W. (2020). "Origin and Evolution of the Central Andes: Deserts, Salars, Lakes, and Volcanoes," in Microbial Ecosystems in Central Andes Extreme Environments (Cham: Springer), 3-19. doi:10.1007/978-3-030-36192-1_1

Angel de Pablo, M., and Komatsu, G. (2009). Possible Pingo fields in the Utopia basin, Mars: Geological and Climatical Implications. Icarus 199, 49-74. doi:10.1016/j.icarus.2008.09.007

Artieda, O., Davila, A., Wierzchos, J., Buhler, P., Rodríguez-Ochoa, R., Pueyo, J., et al. (2015). Surface Evolution of Salt-Encrusted Playas under Extreme and Continued Dryness. Earth Surf. Process. Landforms 40, 1939-1950. doi:10.1002/esp.3771

Artieda, O. (2013). Morphology and Micro-fabrics of Weathering Features on Gyprock Exposures in a Semiarid Environment (Ebro Tertiary Basin, NE Spain). Geomorphology 196, 198-210. doi:10.1016/j.geomorph.2012.03.020

Bada, J., Zent, A., Grunthaner, F., Quinn, R., Navarro-Gonzalez, R., Gomez-Silva, B., et al. (2003). "ASTROBIOLAB: A mobile Biotic and Soil Analysis

\section{AUTHOR CONTRIBUTIONS}

NWH, KWR, MP, and NAC conceived and designed the study. NWH, MHH, KWR, MP, NAC, CT-C, OC, GCD, CD, JLB, VCG, DS, PS, MM, JM, NN, CR, PS, KLR, CJR, and DW analyzed and interpreted the data. NWH, MHH, KWR, MP, NN, NAC, CT-C, OC, CR, KLR, CJR, DW, and VP conducted the investigation. NAC acquired the funding. NWH, MHH, KWR, MP, NAC, GCD, JM, NN, KLR wrote the manuscript.

\section{FUNDING STATEMENT}

This study was supported by the NASA Astrobiology Institute (NAI) via Grant No. NNA15BB01A (N. A. Cabrol, PI).

\section{ACKNOWLEDGMENTS}

NWH acknowledges Nancy E. Hulbirt, Suntikoon Supanut, and Brianna McKay for assistance with figures and data entry. Campoalto provided logistical support in Chile. $\mathrm{MHH}$ acknowledges Cartalytics for the free use of their software.

\section{SUPPLEMENTARY MATERIAL}

The Supplementary Material for this article can be found online at: https://www.frontiersin.org/articles/10.3389/fspas.2021.797591/ full\#supplementary-material

Supplementary Figure $\mathbf{S} \mathbf{1}$ | Profile across the western Andean front. (A) Shaded DEM. (B) Map. (C) Satellite image. (D) Profile along green line in $(\mathbf{A}, \mathbf{B}, \mathbf{C})$ from west to east. Maps and cross section were created in Cartalytics (www.cltix.com); aerial imagery and topo map are downloaded from the Leaflet open-source library (www. cltix.com).

Supplementary Figure S2 | Spectra of gypsum samples from Salar de Pajonales. (A) X-ray diffractogram showing gypsum and calcite peaks. (B) Raman spectra with gypsum and anhydrite bands labeled. (C) IR spectra with gypsum and anhydrite bands labeled.

Laboratory," in Sixth International Conference on Mars, Pasadena, Calif: Citeseer, Germany, 10 May 1842 (Springer).

Barrett, B. S., Campos, D. A., Veloso, J. V., and Rondanelli, R. (2016). Extreme Temperature and Precipitation Events in March 2015 in central and Northern Chile. J. Geophys. Res. Atmos. 121, 4563-4580. doi:10.1002/2016jd024835

Benison, K. C. (2017). Gypsum Gravel Devils in Chile: Movement of Largest Natural Grains by Wind? Geology 45, 423-426. doi:10.1130/g38901.1

Betancourt, J. L., Latorre, C., Rech, J. A., Quade, J., and Rylander, K. A. (2000). A 22,000-year Record of Monsoonal Precipitation from Northern Chile's Atacama Desert. Science 289, 1542-1546. doi:10.1126/science.289.5484.1542

Bishop, J. L., Yeşilbaş, M., Hinman, N. W., Burton, Z. F. M., Englert, P. A. J., Toner, J. D., et al. (2021). Martian Subsurface Cryosalt Expansion and Collapse as Trigger for Landslides. Sci. Adv. 7, eabe4459. doi:10.1126/sciadv.abe4459

Bobst, A. L., Lowenstein, T. K., Jordan, T. E., Godfrey, L. V., Ku, T.-L., and Luo, S. (2001). A 106ka paleoclimate record from drill core of the Salar de Atacama, northern Chile. Palaeogeogr. Palaeoclimatol. Palaeoecol. 173, 21-42. doi:10.1016/s0031-0182(01)00308-x

Bozkurt, D., Rondanelli, R., Garreaud, R., and Arriagada, A. (2016). Impact of Warmer Eastern Tropical Pacific SST on the March 2015 Atacama Floods. Monthly Weather Rev. 144, 4441-4460. doi:10.1175/mwr-d-16-0041.1 
Brooker, L. M., Balme, M. R., Conway, S. J., Hagermann, A., Barrett, A. M., Collins, G. S., et al. (2018). Clastic Polygonal Networks Around Lyot Crater, Mars: Possible Formation Mechanisms from Morphometric Analysis. Icarus 302, 386-406. doi:10.1016/j.icarus.2017.11.022

Burr, D. M., Tanaka, K. L., and Yoshikawa, K. (2009). Pingos on Earth and Mars. Planet. Space Sci. 57, 541-555. doi:10.1016/j.pss.2008.11.003

Cabré, A., Remy, D., Aguilar, G., Carretier, S., and Riquelme, R. (2020). Mapping Rainstorm Erosion Associated with an Individual Storm from InSAR Coherence Loss Validated by Field Evidence for the Atacama Desert. Earth Surf. Process. Landforms 45, 2091-2106. doi:10.1002/esp.4868

Cabrol, N. A., Chong-Diaz, G., Stoker, C. R., Gulick, V. C., Landheim, R., Lee, P., et al. (2001). Nomad Rover Field Experiment, Atacama Desert, Chile: 1. Science Results Overview. J. Geophys. Res. 106, 7785-7806. doi:10.1029/1999je001166

Cabrol, N. A., Feister, U., Hãøder, D.-P., Piazena, H., Grin, E. A., and Klein, A. (2014). Record Solar UV Irradiance in the Tropical Andes. Front. Environ. Sci. 2, 19, 2014 . Article No.: 19. doi:10.3389/fenvs.2014.00019

Cabrol, N. A., Grin, E. A., Chong, G., Häder, D. P., Minkley, E., Yu, Y., et al. (2010). "Dynamics of Declining lake Habitat in Changing Climate," in Lakes on Mars (Elsevier), 347-369. doi:10.1016/b978-0-444-52854-4.00013-1

Cabrol, N. A., and Grin, E. A. (2010). Lakes on Mars. Elsevier.

Cabrol, N. A., Grin, E. A., Zippi, P., Noffke, N., and Winter, D. (2018). "Evolution of Altiplanic Lakes at the Pleistocene/holocene Transition: a Window into Early mars Declining Habitability, Changing Habitats, and Biosignatures," in From Habitability to Life on Mars (Elsevier), 153-177. doi:10.1016/b978-0-12809935-3.00006-2

Cabrol, N. A., McKay, C. P., Grin, E. A., Kiss, K. T., Ács, É., Tóth, B., et al. (2009). Signatures of Habitats and Life in Earth's High-Altitude Lakes: Clues to Noachian Aqueous Environments on Mars.

Cabrol, N. A. (2018). The Coevolution of Life and Environment on Mars: An Ecosystem Perspective on the Robotic Exploration of Biosignatures. Astrobiology 18, 1-27. doi:10.1089/ast.2017.1756

Cabrol, N. A., Wettergreen, D., Warren-Rhodes, K., Grin, E. A., Moersch, J., Diaz, G. C., et al. (2007). Life in the Atacama: Searching for Life with Rovers (Science Overview). J. Geophys. Res. Biogeosciences 112, 1. doi:10.1029/2006jg000298

Calaforra, J. M., and Pulido-Bosch, A. (1997). Peculiar Landforms in the gypsum Karst of Sorbas (southeastern Spain). Carbonates Evaporites 12, 110-116. doi:10.1007/bf03175809

Casertano, L. (1963). General Characteristics of Active Andean Volcanoes and a Summary of Their Activities during Recent Centuries. Bull. Seismological Soc. America 53, 1415-1433. doi:10.1785/bssa0530061415

Caswell, T. E., and Milliken, R. E. (2017). Evidence for Hydraulic Fracturing at Gale Crater, Mars: Implications for Burial Depth of the Yellowknife Bay Formation. Earth Planet. Sci. Lett. 468, 72-84. doi:10.1016/j.epsl.2017.03.033

Charola, A. E., Puhringer, J., and Steiger, M. (2007). Gypsum: a Review of its Role in the Deterioration of Building Materials. Environ. Geology 52, 207-220. doi:10.1007/s00254-006-0566-9

Charrier, R., Pinto, L., and Rodríguez, M. P. (2007). "Tectonostratigraphic Evolution of the Andean Orogen in Chile," in The Geology of Chile, 21-114.

Chepstow-Lusty, A., Bush, M. B., Frogley, M. R., Baker, P. A., Fritz, S. C., and Aronson, J. (2005). Vegetation and Climate Change on the Bolivian Altiplano between 108,000 and 18,000 Yr Ago. Quat. Res. 63, 90-98. doi:10.1016/ j.yqres.2004.09.008

Chong Diaz, G., Demergasso, C., Urrutia Meza, J., and Vargas a, M. (2020). The Saline Domain of Northern Chile and its Industrial mineral Deposits. Boletin De La Sociedad Geologica Mexicana 72, 1. doi:10.18268/bsgm2020v72n3a020720

Davila, A. F., Duport, L. G., Melchiorri, R., Jänchen, J., Valea, S., De Los Rios, A., et al. (2010). Hygroscopic Salts and the Potential for Life on Mars. Astrobiology 10, 617-628. doi:10.1089/ast.2009.0421

Davila, A. F., and Schulze-Makuch, D. (2016). The Last Possible Outposts for Life on Mars. Astrobiology 16, 159-168. doi:10.1089/ast.2015.1380

Davis, W. L., De Pater, I., and McKay, C. P. (2010). Rain Infiltration and Crust Formation in the Extreme Arid Zone of the Atacama Desert, Chile. Planet. Space Sci. 58, 616-622. doi:10.1016/j.pss.2009.08.011

De Wet, C. B., De Wet, A. P., Godfrey, L., Driscoll, E., Patzkowsky, S., Xu, C., et al. (2020). Pliocene Short-Term Climate Changes Preserved in continental Shallow Lacustrine-Palustrine Carbonates: Western Opache Formation, Atacama Desert, Chile. Geol. Soc. America Bull. 132, 1795-1816. doi:10.1130/b35227.1
DeCelles, P. G., Zandt, G., Beck, S. L., Currie, C. A., Ducea, M. N., Kapp, P., et al. (2015). Cyclical Orogenic Processes in the Cenozoic central Andes. Memoir Geol. Soc. America 212, 459-490. Geodynamics of a Cordilleran Orogenic System: the Central Andes of Argentina and Northern Chile. doi:10.1130/ 2015.1212(22)

Díaz, F. P., Latorre, C., Maldonado, A., Quade, J., and Betancourt, J. L. (2012). Rodent Middens Reveal Episodic, Long-distance Plant Colonizations across the Hyperarid Atacama Desert over the Last 34,000 Years. J. Biogeogr. 39, 510-525.

Diederich, J. L., Wennrich, V., Bao, R., Buettner, C., Bolten, A., Brill, D., et al. (2020). A 68 Ka Precipitation Record from the Hyperarid Core of the Atacama Desert in Northern Chile. Glob. Planet. Change 184. doi:10.1016/ j.gloplacha.2019.103054

Dundas, C. M., and Mcewen, A. S. (2010). An Assessment of Evidence for Pingos on Mars Using HiRISE. Icarus 205, 244-258. doi:10.1016/ j.icarus.2009.02.020

El-Maarry, M. R., Watters, W., Mckeown, N. K., Carter, J., Noe Dobrea, E., Bishop, J. L., et al. (2014). Potential Desiccation Cracks on Mars: A Synthesis from Modeling, Analogue-Field Studies, and Global Observations. Icarus 241, 248-268. doi:10.1016/j.icarus.2014.06.033

Fairén, A. G., Davila, A. F., Lim, D., Bramall, N., Bonaccorsi, R., Zavaleta, J., et al. (2010). Astrobiology through the Ages of Mars: The Study of Terrestrial Analogues to Understand the Habitability of Mars. Astrobiology 10, 821-843. doi:10.1089/ast.2009.0440

Farías, M. E., and Acuña, L. A. S. (2020). "Modern Microbial Mats and Endoevaporite Systems in Andean Lakes: A General Approach," in Microbial Ecosystems in Central Andes Extreme Environments (Springer), 21-33.

Fernanders, M. S., Gough, R. V., Chevrier, V. F., Schiffman, Z. R., Ushijima, S. B., Martinez, G. M., et al. (2022). Water Uptake by Chlorate Salts under Marsrelevant Conditions. Icarus 371, 114715. doi:10.1016/j.icarus.2021.114715

Fiahaut, J., Martinot, M., Bishop, J. L., Davies, G. R., and Potts, N. J. (2017). Remote Sensing and In Situ Mineralogic Survey of the Chilean Salars: An Analog to Mars Evaporate Deposits? Icarus 282, 152-173.

Finstad, K., Pfeiffer, M., McNicol, G., Barnes, J., Demergasso, C., Chong, G., et al. (2016). Rates and Geochemical Processes of Soil and Salt Crust Formation in Salars of the Atacama Desert, Chile. Geoderma 284, 57-72. doi:10.1016/ j.geoderma.2016.08.020

García, M., Riquelme, R., Farías, M., Hérail, G., and Charrier, R. (2011). Late Miocene-Holocene canyon Incision in the Western Altiplano, Northern Chile: Tectonic or Climatic Forcing? J. Geol. Soc. 168, 1047-1060. doi:10.1144/001676492010-134

Garreaud, R. D., Vuille, M., Compagnucci, R., and Marengo, J. (2009). Present-day South American Climate. Palaeogeogr. Palaeoclimatol. Palaeoecol. 281, 180-195. doi:10.1016/j.palaeo.2007.10.032

Garreaud, R. (2000). Intraseasonal Variability of Moisture and Rainfall over the South American Altiplano. Mon. Wea. Rev. 128, 3337-3346. doi:10.1175/15200493(2000) $128<3337$ :ivomar $>2.0 . c 0 ; 2$

Garreaud, R., Vuille, M., and Clement, A. C. (2003). The Climate of the Altiplano: Observed Current Conditions and Mechanisms of Past Changes. Palaeogeogr. Palaeoclimatol. Palaeoecol. 194, 5-22. doi:10.1016/s0031-0182(03)00269-4

Geyh, M. A., Grosjean, M., Núñez, L., and Schotterer, U. (1999). Radiocarbon Reservoir Effect and the Timing of the Late-Glacial/early Holocene Humid Phase in the Atacama Desert (Northern Chile). Quat. Res. 52, 143-153. doi:10.1006/qres.1999.2060

Glines, N. H., and Gulick, V. C. (in review). Paleolakes and Channels on the Floor of Lyot Crater. Mars: Icarus.

Global Volcanism Program (2013). Lastarria (355120) Volcanoes of the World. Washington, D.C.: Smithsonian Institute. v.4.10.2 (24 Aug 2021) [Online] (Accessed Aug 25, 2021).

Gómez-Silva, B. (2010). "On the Limits Imposed to Life by the Hyperarid Atacama Desert in Northern Chile," in Astrobiology: Emergence, Search and Detection of Life (United States: American Scientific Publishers), 199-213.

Gómez-Silva, B., Rainey, F. A., Warren-Rhodes, K. A., McKay, C. P., and NavarroGonzález, R. (2008). "Atacama Desert Soil Microbiology," in Microbiology of Extreme Soils (Springer), 117-132.

Greeley, R., and Guest, J. (1987). Geologic Map of the Eastern Equatorial Region of Mars. USGS Miscellaneous Investigations Series Map I-1802-B, as part of the Atlas of Mars, 1:15,000,000 Geologic Series. Reston, VA: US Geological Survey. 
Grosjean, M., Van Leeuwen, J. F. N., Van Der Knaap, W. O., Geyh, M. A., Ammann, B., Tanner, W., et al. (2001). A 22,000 14C Year BP Sediment and Pollen Record of Climate Change from Laguna Miscanti $\left(23^{\circ} \mathrm{S}\right)$, Northern Chile. Glob. Planet. Change 28, 35-51. doi:10.1016/s0921-8181(00)00063-1

Grotzinger, J. P., Sumner, D. Y., Kah, L. C., Stack, K., Gupta, S., Edgar, L., et al.Team, M.S.L.S. (2014). A Habitable Fluvio-Lacustrine Environment at Yellowknife Bay, Gale Crater, Mars. Science 343, 1242777. doi:10.1126/ science. 1242777

Grunthaner, F. J., Willis, P., Amashukeli, X., Bada, J. L., Aubrey, A., Mathies, R. A., et al. (2006). The Urey Instrument: Ultra-sensitive Chiral Biomarker Detection with Correlated Soil Oxidant Profiling. Astrobiology 6, 242-243.

Gulick, V. C., Glines, N., Hart, S., and Freeman, P. (2019). Geomorphological Analysis of Gullies on the central Peak of Lyot Crater, Mars. Geol. Soc. Lond. Spec. Publications 467, 233-265. doi:10.1144/sp467.17

Gutiérrez, F., and Cooper, A. (2013). 6.33 Surface Morphology of Gypsum Karst.

Gutiérrez, M. (2005). "Desert Lakes: Playa Lakes and Sebkhas," in Developments in Earth Surface Processes. Editor M. Gutiérrez (Amsterdam, Netherlands: Elsevier), 383-405.

Häder, D.-P., and Cabrol, N. A. (2018). "UV and Life Adaptation Potential on Early Mars: Lessons from Extreme Terrestrial Analogs," in From Habitability to Life on Mars (Elsevier), 233-248.

Häder, D. P., and Cabrol, N. A. (2020). Monitoring of Solar Irradiance in the High Andes. Photochem. Photobiol. 96, 1133-1139. doi:10.1111/php.13276

Hallsworth, J. E. (2020). Salt Deliquescence Can Support Extraterrestrial Life. Nat. Astron. 4, 739-740. doi:10.1038/s41550-020-1081-8

Haschke, M., Gunther, A., Melnick, D., Echtler, H., Reutter, K. J., Scheuber, E., et al. (2006). Central and Southern Andean Tectonic Evolution Inferred from Arc Magmatism. Andes: Active Subduction Orogeny 1, 337-353. doi:10.1007/978-3540-48684-8_16

Haschke, M. R., Scheuber, E., Gunther, A., and Reutter, K.-J. (2002). Evolutionary Cycles during the Andean Orogeny: Repeated Slab Breakoff and Flat Subduction? Terra Nova 14, 49-55. doi:10.1046/j.1365-3121.2002.00387.x

Hofmann, M. H., Hinman, N. W., Phillips, M. P., McInenly, M., Chong Diaz, G., Noffke, N., et al. (in review). An Integrated Process Model of gypsum Dome Morphology Formation and its Relevance in the Search for Life on Mars. Scientific Rep. 1, 1.

Hooper, J., Marx, S. K., May, J.-H., Lupo, L. C., Kulemeyer, J. J., Pereira, E. d. l. Á., et al. (2020). Dust Deposition Tracks Late-Holocene Shifts in Monsoon Activity and the Increasing Role of Human Disturbance in the PunaAltiplano, Northwest Argentina. The Holocene 30, 519-536. doi:10.1177/ 0959683619895814

Houston, J., and Hartley, A. J. (2003). The central Andean West-Slope Rainshadow and its Potential Contribution to the Origin of HYPER-ARIDITY in the Atacama Desert. Int. J. Climatol. 23, 1453-1464. doi:10.1002/joc.938

Houston, J. (2006). Variability of Precipitation in the Atacama Desert: Its Causes and Hydrological Impact. Int. J. Climatol. 26, 2181-2198. doi:10.1002/joc.1359

Jordan, T. E., Isacks, B. L., Ramos, V. A., and Allmendinger, R. W. (1983). Mountain Building in the central Andes. Episodes 3, 20-26.

Jowett, E. C., Cathles, L. M., and Davis, B. W. (1993). Predicting Depths of gypsum Dehydration in Evaporitic Sedimentary Basins. AAPG Bulletin-American Assoc. Pet. Geologists 77, 402-413. doi:10.1306/bdff8c22-1718-11d7-8645000102c1865d

Kereszturi, A., Aszalós, J. M., Heiling, Z., Ignéczi, Á., Kapui, Z., Király, C., et al. (2020). Cold, dry, windy, and UV irradiated: Surveying Mars-relevant conditions in Ojos del Salado Volcano (Andes Mountains, Chile). Astrobiology 20, 677-683. doi:10.1089/ast.2019.2165

Kite, E. S. (2019). Geologic Constraints on Early Mars Climate. Space Sci. Rev. 215, 2019. doi:10.1007/s11214-018-0575-5

Koponen, A., Kataja, M., and Timonen, J. (1997). Permeability and Effective Porosity of Porous media. Phys. Rev. E. 56, 3319-3325. doi:10.1103/physreve.56.3319

Lafuente, B., Downs, R. T., Yang, H., and Stone, N. (2015). "The Power of Databases: The RRUFF Project," in Highlights in Mineralogical Crystallography. Editors T. Armbruster and R. M. Danisi (Berlin, Germany: W. De Gruyter), 1-30.

Langsdorf, E., and Britt, D. (2005). "Classification and Distribution of Patterned Ground in the Southern Hemisphere of Mars," in 36th Annual Lunar and Planetary Science Conference.

Latorre, C., Betancourt, J. L., and Arroyo, M. T. K. (2006). Late Quaternary Vegetation and Climate History of a Perennial River canyon in the Río Salado basin $\left(22^{\circ} \mathrm{S}\right)$ of Northern Chile. Quat. Res. 65, 450-466. doi:10.1016/j.yqres.2006.02.002
Lefort, A., Russell, P. S., Thomas, N., Mcewen, A. S., Dundas, C. M., and Kirk, R. L. (2009). Observations of Periglacial Landforms in Utopia Planitia with the High Resolution Imaging Science Experiment (HiRISE). J. Geophys. Research-Planets 114, e4. doi:10.1029/2008je003264

Levy, J., Head, J., and Marchant, D. (2009). Thermal Contraction Crack Polygons on Mars: Classification, Distribution, and Climate Implications from HiRISE Observations. J. Geophys. Research-Planets 114, e1. doi:10.1029/2008je003273

Maldonado, A., Betancourt, J. L., Latorre, C., and Villagran, C. (2005). Pollen Analyses from a 50 000-yr Rodent Midden Series in the Southern Atacama Desert ( $25^{\circ} 30^{\prime}$ S). J. Quat. Sci. 20, 493-507. doi:10.1002/jqs.936

Malin, M. C., and Edgett, K. S. (2000). Evidence for Recent Groundwater Seepage and Surface Runoff on Mars. Science 288, 2330-2335. doi:10.1126/science.288.5475.2330

Mangold, N. (2005). High Latitude Patterned Grounds on Mars: Classification, Distribution and Climatic Control. Icarus 174, 336-359. doi:10.1016/j.icarus.2004.07.030

Mangold, N., Maurice, S., Feldman, W. C., Costard, F., and Forget, F. (2004). Spatial Relationships between Patterned Ground and Ground Ice Detected by the Neutron Spectrometer on Mars. J. Geophys. Research-Planets 109, 1. doi:10.1029/2004je002235

Marais, D. J. D. (2010). "Marine Hypersaline Microcoleus-Dominated Cyanobacterial Mats in the Saltern at Guerrero Negro, Baja California Sur, Mexico: A System-Level Perspective," in Microbial Mats (Springer), 401-420. doi:10.1007/978-90-481-3799-2_21

McKay, C. P., Friedmann, E. I., Gómez-Silva, B., Cáceres-Villanueva, L., Andersen, D. T., and Landheim, R. (2003). Temperature and Moisture Conditions for Life in the Extreme Arid Region of the Atacama Desert: Four Years of Observations Including the El Niño of 1997-1998. Astrobiology 3, 393-406. doi:10.1089/ 153110703769016460

Meseguer-Ruiz, O., Ponce-Philimon, P. I., Baltazar, A., Guijarro, J. A., SerranoNotivoli, R., Olcina Cantos, J., et al. (2020). Synoptic Attributions of Extreme Precipitation in the Atacama Desert (Chile). Clim. Dyn. 55, 3431-3444. doi:10.1007/s00382-020-05455-4

Morgenstern, A., Hauber, E., Reiss, D., Van Gasselt, S., Grosse, G., and Schirrmeister, L. (2007). Deposition and Degradation of a Volatile-Rich Layer in Utopia Planitia and Implications for Climate History on Mars. J. Geophys. Research-Planets 112, E06010. doi:10.1029/2006je002869

Nazari-Sharabian, M., Aghababaei, M., Karakouzian, M., and Karami, M. (2020). Water on Mars-A Literature Review. Galaxies 8, 40. doi:10.3390/galaxies8020040

Neal, J. T., Langer, A. M., and Kerr, P. F. (1968). Giant Desiccation Polygons of Great Basin Playas. Geol. Soc. America Bull. 79, 69. doi:10.1130/00167606(1968)79[69:gdpogb]2.0.co;2

Noffke, N. (2010). Geobiology: Microbial Mats in sandy Deposits from the Archean Era to Today. Springer Science \& Business Media.

Ortega, C., Vargas, G., Rojas, M., Rutllant, J. A., Muñoz, P., Lange, C. B., et al. (2019). Extreme ENSO-Driven Torrential Rainfalls at the Southern Edge of the Atacama Desert during the Late Holocene and Their Projection into the 21th century. Glob. Planet. Change 175, 226-237. doi:10.1016/j.gloplacha.2019.02.011

Otálora, F., Criado-Reyes, J., Baselga, M., Canals, A., Verdugo-Escamilla, C., and García Ruiz, J. M. (2020). Hydrochemical and mineralogical evolution through evaporitic processes in Salar de Llamara brines (Atacama, Chile). ACS Earth Space Chem. 4, 882-896. doi:10.1021/acsearthspacechem.0c00085

Pál, B., and Kereszturi, Á. (2020). Annual and Daily Ideal Periods for Deliquescence at the landing Site of InSight Based on GCM Model Calculations. Icarus 340, 113639. doi:10.1016/j.icarus.2020.113639

Palacios, D., Stokes, C. R., Phillips, F. M., Clague, J. J., Alcala-Reygosa, J., Andres, N., et al. (2020). The Deglaciation of the Americas during the Last Glacial Termination. Earth-Science Rev. 203. doi:10.1016/j.earscirev.2020.103113

Pechmann, J. C. (1980). The Origin of Polygonal Troughs on the Northern plains of Mars. Icarus 42, 185-210. doi:10.1016/0019-1035(80)90071-8

Pfeiffer, M., Latorre, C., Santoro, C. M., Gayo, E. M., Rojas, R., Carrevedo, M. L., et al. (2018). Chronology, Stratigraphy and Hydrological Modelling of Extensive Wetlands and Paleolakes in the Hyperarid Core of the Atacama Desert during the Late Quaternary. Quat. Sci. Rev. 197, 224-245. doi:10.1016/j.quascirev.2018.08.001

Pfeiffer, M., Morgan, A., Heimsath, A., Jordan, T., Howard, A., and Amundson, R. (2021). Century Scale Rainfall in the Absolute Atacama Desert: Landscape Response and Implications for Past and Future Rainfall. Quat. Sci. Rev. 254, 106797. doi:10.1016/j.quascirev.2021.106797

Phillips, M. S., Moersch, J. E., Cabrol, N. A., Candela, A., Wettergreen, D., WarrenRhodes, K., et al.Team, T.S.I.N. (2021). Establishing Thresholds of Identification 
for Planetary Features Using Deep Learning: Application to Habitats in a Marsanalog Landscape.

Piatek, J. L., Hardgrove, C., Moersch, J. E., Drake, D. M., Wyatt, M. B., Rampey, M., et al. (2007). Surface and Subsurface Composition of the Life in the Atacama Field Sites from Rover Data and Orbital Image Analysis. J. Geophys. ResearchBiogeosciences 112, 1. doi:10.1029/2006jg000317

Pueyo, J., Demergasso, C., Escudero, L., Chong, G., Cortéz-Rivera, P., SanjurjoSánchez, J., et al. (2021). On the Origin of saline Compounds in Acidic Salt Flats (Central Andean Altiplano). Chem. Geology 1, 120155. doi:10.1016/ j.chemgeo.2021.120155

Quade, J., Dettinger, M., Carrapa, B., Decelles, P., Murray, K., Huntington, K., et al. (2015). The Growth of the central Andes, 22 S-26 S. Geol. Soc. Am. Mem. 12, 277-308. doi:10.1130/2015.1212(15)

Rehak, K., Bookhagen, B., Strecker, M. R., and Echtler, H. P. (2010). The Topographic Imprint of a Transient Climate Episode: the Western Andean Flank between $15 \cdot 5^{\circ}$ and $41 \cdot 5^{\circ}$ S. Earth Surf. Process. Landforms 35, 1516-1534. doi:10.1002/esp.1992

Reiners, P. W., Thomson, S. N., Vernon, A., Willett, S. D., Zattin, M., Einhorn, J., et al. (2015). Geodynamics of a Cordilleran Orogenic System: the Central Andes of Argentina and Northern Chile. Geol. Soc. America 212, 215-249. doi:10.1130/MEM212

Riquelme, R., Hérail, G., Martinod, J., Charrier, R., and Darrozes, J. (2007). Late Cenozoic Geomorphologic Signal of Andean Forearc Deformation and Tilting Associated with the Uplift and Climate Changes of the Southern Atacama Desert $\quad\left(26^{\circ} \mathrm{S}-28^{\circ} \mathrm{S}\right)$. Geomorphology $86, \quad 283-306 . \quad$ doi:10.1016/ j.geomorph.2006.09.004

Risacher, F., and Alonso, H. (2001). Geochemistry of Ash Leachates from the 1993 Lascar Eruption, Northern Chile. Implication for Recycling of Ancient Evaporites. J. Volcanology Geothermal Res. 109, 319-337. doi:10.1016/s0377-0273(01)00198-6

Risacher, F., Alonso, H., and Salazar, C. (2003). The Origin of Brines and Salts in Chilean Salars: a Hydrochemical Review. Earth-Science Rev. 63, 249-293. doi:10.1016/s0012-8252(03)00037-0

Robidoux, P., Rizzo, A. L., Aguilera, F., Aiuppa, A., Artale, M., Liuzzo, M., et al. (2020). Petrological and noble Gas Features of Lascar and Lastarria Volcanoes (Chile): Inferences on Plumbing Systems and Mantle Characteristics. Lithos 370, 105615. doi:10.1016/j.lithos.2020.105615

Schulze-Makuch, D., Wagner, D., Kounaves, S. P., Mangelsdorf, K., Devine, K. G., De Vera, J.-P., et al. (2018). Transitory Microbial Habitat in the Hyperarid Atacama Desert. Proc. Natl. Acad. Sci. USA 115, 2670-2675. doi:10.1073/pnas.1714341115

Seibert, N. M., and Kargel, J. S. (2001). Small-scale Martian Polygonal Terrain: Implications for Liquid Surface Water. Geophys. Res. Lett. 28, 899-902. doi:10.1029/2000gl012093

Soare, R. J., Burr, D. M., and Wan Bun Tseung, J. M. (2005). Possible Pingos and a Periglacial Landscape in Northwest Utopia Planitia. Icarus 174, 373-382. doi:10.1016/j.icarus.2004.11.013

Soare, R. J., Osinski, G. R., and Roehm, C. L. (2008). Thermokarst Lakes and Ponds on Mars in the Very Recent (Late Amazonian) Past. Earth Planet. Sci. Lett. 272, 382-393. doi:10.1016/j.epsl.2008.05.010

Stein, N., Grotzinger, J. P., Schieber, J., Mangold, N., Hallet, B., Sumner, D. Y., et al. (2018). Desiccation Cracks Provide Evidence of lake Drying on Mars, Sutton Island Member, Murray Formation, Gale Crater. Geology 46, E450. doi:10.1130/ g45237y.1

Tanaka, K. L., Skinner, J. A., Jr, Dohm, J. M., Irwin, R. P., III, Kolb, E. J., Fortezzo, C. M., et al. (2014). Geologic Map of Mars.

Urrutia, J., Herrera, C., Custodio, E., Jódar, J., and Medina, A. (2019). Groundwater Recharge and Hydrodynamics of Complex Volcanic Aquifers with a Shallow saline lake: Laguna Tuyajto, Andean Cordillera of Northern Chile. Sci. Total Environ. 697, 134116. doi:10.1016/j.scitotenv.2019.134116

Urrutia, J., Jódar, J., Medina, A., Herrera, C., Chong, G., Urqueta, H., et al. (2018). Hydrogeology and Sustainable Future Groundwater Abstraction from the Agua Verde Aquifer in the Atacama Desert, Northern Chile. Hydrogeol. J. 26, 1989-2007. doi:10.1007/s10040-018-1740-3

Valdés-Pineda, R., V Aldés, J. B., and Garcia-Chevesich, P. (2017). Modelación de crecidas aluvionales en la Cuenca del Río Copiapó, Chile. Ingeniería Del. Agua 21, 135-152. [S.l.]. doi:10.4995/ia.2017.7366

Ward, D. J., Cesta, J. M., Galewsky, J., and Sagredo, E. (2015). Late Pleistocene Glaciations of the Arid Subtropical Andes and New Results from the
Chajnantor Plateau, Northern Chile. Quat. Sci. Rev. 128, 98-116. doi:10.1016/j.quascirev.2015.09.022

Ward, D., Thornton, R., and Cesta, J. (2017). Across the Arid diagonal: Deglaciation of the Western Andean Cordillera in Southwest Bolivia and Northern Chile. Cig. 43, 667-696. doi:10.18172/cig.3209

Warren, J. K. (2016). Evaporites: A Geological Compendium. Springer.

Warren-Rhodes, K., Cabrol, N. A., Phillips, M., Tebes Cayo, C., Hinman, N. W., Rhodes, K. L., et al. (in review). Decoding Microbial Spatial Patterns as a Blueprint for Biosignature Detection on Mars and Beyond. Astrobiology 15, 998. doi:10.1089/ast.2015.1374

Warren-Rhodes, K., Weinstein, S., Dohm, J., Piatek, J., Minkley, E., Hock, A., et al. (2007a). Searching for Microbial Life Remotely: Satellite-To-Rover Habitat Mapping in the Atacama Desert, Chile. J. Geophys. Research-Biogeosciences 112, 1. doi:10.1029/2006jg000283

Warren-Rhodes, K., Weinstein, S., Piatek, J. L., Dohm, J., Hock, A., Minkley, E., et al. (2007b). Robotic Ecological Mapping: Habitats and the Search for Life in the Atacama Desert. J. Geophys. Research-Biogeosciences 112, 1. doi:10.1029/2006jg000301

Wettergreen, D., Cabrol, N., Baskaran, V., Calderón, F., Heys, S., Jonak, D., et al. (2005). "Second Experiments in the Robotic Investigation of Life in the Atacama Desert of Chile," in Proc. 8th International Symposium on Artificial Intelligence, Robotics and Automation in Space: Citeseer).

Wierzchos, J., Ascaso, C., Artieda, O., and Casero, M. C. (2020). "The Desert Polyextreme Environment and Endolithic Habitats," in Microbial Ecosystems in Central Andes Extreme Environments: Biofilms, Microbial Mats, Microbialites and Endoevaporites. Editor M. E. Farías (Switzerland: Springer), 37-49. doi:10.1007/978-3-030-36192-1_3

Wierzchos, J., Cámara, B., De Los Ríos, A., Davila, A. F., Sánchez Almazo, I. M., Artieda, O., et al. (2011). Microbial Colonization of Ca-Sulfate Crusts in the Hyperarid Core of the Atacama Desert: Implications for the Search for Life on Mars. Geobiology 9, 44-60. doi:10.1111/j.1472-4669.2010.00254.x

Wilcox, A. C., Escauriaza, C., Agredano, R., Mignot, E., Zuazo, V., Otárola, S., et al. (2016). An Integrated Analysis of the March 2015 Atacama Floods. Geophys. Res. Lett. 43, 8035-8043. doi:10.1002/2016gl069751

Wilhelm, M. B., Davila, A. F., Parenteau, M. N., Jahnke, L. L., Abate, M., Cooper, G., et al. (2018). Constraints on the Metabolic Activity of Microorganisms in Atacama Surface Soils Inferred from Refractory Biomarkers: Implications for Martian Habitability and Biomarker Detection. Astrobiology 18, 955-966. doi:10.1089/ast.2017.1705

Wordsworth, R., Knoll, A. H., Hurowitz, J., Baum, M., Ehlmann, B. L., Head, J. W., et al. (2021). A Coupled Model of Episodic Warming, Oxidation and Geochemical Transitions on Early Mars. Nat. Geosci. 14, 127-132. doi:10.1038/s41561-021-00701-8

Yilmaz, I., and Karacan, E. (2005). Slaking Durability and its Effect on the Doline Formation in the gypsum. Environ. Geol. 47, 1010-1016. doi:10.1007/s00254005-1234-1

Young, B. W., and Chan, M. A. (2017). Gypsum Veins in Triassic Moenkopi Mudrocks of Southern Utah: Analogs to Calcium Sulfate Veins on Mars. J. Geophys. Res. Planets 122, 150-171. doi:10.1002/2016je005118

Conflict of Interest: The authors declare that the research was conducted in the absence of any commercial or financial relationships that could be construed as a potential conflict of interest.

Publisher's Note: All claims expressed in this article are solely those of the authors and do not necessarily represent those of their affiliated organizations, or those of the publisher, the editors and the reviewers. Any product that may be evaluated in this article, or claim that may be made by its manufacturer, is not guaranteed or endorsed by the publisher.

Copyright (c 2022 Hinman, Hofmann, Warren-Rhodes, Phillips, Noffke, Cabrol, Chong Diaz, Demergasso, Tebes-Cayo, Cabestrero, Bishop, Gulick, Summers, Sobron, McInenly, Moersch, Rodriguez, Sarazzin, Rhodes, Riffo Contreras, Wettergreen and Parro. This is an open-access article distributed under the terms of the Creative Commons Attribution License (CC BY). The use, distribution or reproduction in other forums is permitted, provided the original author(s) and the copyright owner(s) are credited and that the original publication in this journal is cited, in accordance with accepted academic practice. No use, distribution or reproduction is permitted which does not comply with these terms. 